\title{
Strategy for simultaneously increasing both hardness and toughness in ZrB2-rich Zr1-xTaxBy thin films
}

Babak Bakhit, David Engberg, Jun Lu, Johanna Rosén, Hans Högberg, Lars Hultman, Ivan Petrov, Joseph E Greene and Grzegorz Greczynski

The self-archived postprint version of this journal article is available at Linköping University Institutional Repository (DiVA):

http://urn.kb.se/resolve?urn=urn:nbn:se:liu:diva-159001

N.B.: When citing this work, cite the original publication.

Bakhit, B., Engberg, D., Lu, J., Rosén, J., Högberg, H., Hultman, L., Petrov, I., Greene, J. E,

Greczynski, G., (2019), Strategy for simultaneously increasing both hardness and toughness in ZrB2rich Zr1-xTaxBy thin films, Journal of Vacuum Science \& Technology. A. Vacuum, Surfaces, and Films, 37(3), 031506. https://doi.org/10.1116/1.5093170

Original publication available at:

https://doi.org/10.1116/1.5093170

Copyright: AIP Publishing

http://www.aip.org/ 


\title{
Strategy for simultaneously increasing both hardness and toughness in $\mathrm{ZrB}_{2}$-rich $\mathrm{Zr}_{1-\mathrm{x}} \mathrm{Ta}_{\mathbf{x}} \mathrm{B}_{\mathrm{y}}$ thin films
}

\author{
Babak Bakhit,,${ }^{\mathrm{a},}$ David L.J. Engberg, ${ }^{\mathrm{a}}$ Jun Lu, ${ }^{\mathrm{a}}$ Johanna Rosen, ${ }^{\mathrm{a}}$ Hans Högberg, ${ }^{\mathrm{a}}$ \\ Lars Hultman, ${ }^{\mathrm{a}}$ Ivan Petrov, ${ }^{\mathrm{a}, \mathrm{b}}$ J.E. Greene, ${ }^{\mathrm{a}, \mathrm{b}}$ and Grzegorz Greczynski ${ }^{\mathrm{a}}$ \\ ${ }^{a}$ Thin Film Physics Division, Department of Physics (IFM), Linköping University, \\ SE-58183 Linköping, Sweden \\ ${ }^{\mathrm{b}}$ Frederick Seitz Materials Research Laboratory and Department Materials Science, \\ University of Illinois, Urbana, Illinois 61801, USA
}

\begin{abstract}
Refractory transition-metal (TM) diborides exhibit inherent hardness. However, this is not always sufficient to prevent failure in applications involving high mechanical and thermal stress, since hardness is typically accompanied by brittleness leading to crack formation and propagation. Toughness, the combination of hardness and ductility, is required to avoid brittle fracture. Here, we demonstrate a strategy for simultaneously enhancing both hardness and ductility of $\mathrm{ZrB}_{2}$-rich thin films grown in pure $\mathrm{Ar}$ on $\mathrm{Al}_{2} \mathrm{O}_{3}(0001)$ and $\mathrm{Si}(001)$ substrates at $475{ }^{\circ} \mathrm{C}$. $\mathrm{ZrB} 2.4$ layers are deposited by de magnetron sputtering (DCMS) from a $\mathrm{ZrB}_{2}$ target; while $\mathrm{Zr}_{1-\mathrm{x}} \mathrm{Ta}_{\mathrm{x}} \mathrm{B}_{\mathrm{y}}$ alloy films are grown, thus varying the $\mathrm{B} /$ metal ratio as a function of $\mathrm{x}$, by adding pulsed high-power impulse magnetron sputtering (HiPIMS) from a Ta target to deposit $\mathrm{Zr}_{1-\mathrm{x}} \mathrm{Ta}_{\mathrm{x}} \mathrm{B}_{\mathrm{y}}$ alloy films using hybrid Ta-HiPIMS/ZrB2-DCMS sputtering with a substrate bias synchronized to the metal-rich portion of each HiPIMS pulse. The average power $\mathcal{P}_{\mathrm{Ta}}$ (and pulse frequency) applied to the HiPIMS Ta target is varied from 0 to $1800 \mathrm{~W}(0$ to $300 \mathrm{~Hz})$ in increments of $600 \mathrm{~W}(100 \mathrm{~Hz})$. The resulting boron-to-metal ratio, $\mathrm{y}=\mathrm{B} /(\mathrm{Zr}+\mathrm{Ta})$, in as-deposited $\mathrm{Zr}_{1-\mathrm{x}} \mathrm{Ta}_{\mathrm{x}} \mathrm{B}_{\mathrm{y}}$ films decreases from 2.4 to 1.5 as $\mathcal{P}_{\mathrm{Ta}}$ is increased from 0 to $1800 \mathrm{~W}$, while $\mathrm{x}$ increases from 0 to 0.3 .

\footnotetext{
${ }^{*}$ Corresponding author.

Email address: babak.bakhit@liu.se (B. Bakhit)
} 
A combination of $\mathrm{x}$-ray diffraction (XRD), glancing-angle $\mathrm{XRD}$, transmission electron microscopy (TEM), analytical Z-contrast scanning TEM (STEM), electron energy-loss spectroscopy, energy-dispersive $\mathrm{x}$-ray spectroscopy, $\mathrm{x}$-ray photoelectron spectroscopy, and atomprobe tomography reveal that all films have the hexagonal $\mathrm{AlB}_{2}$ crystal structure with a columnar nanostructure, in which the column boundaries of layers with $0 \leq \mathrm{x}<0.2$ are B-rich, whereas those with $x \geq 0.2$ are Ta-rich. The nanostructural transition, combined with changes in average column widths, results in an $\sim 20 \%$ increase in hardness, from 35 to $42 \mathrm{GPa}$, with a simultaneous increase of $\sim 30 \%$ in nanoindentation toughness, from 4.0 to $5.2 \mathrm{MPa} \sqrt{\mathrm{m}}$.

Keywords: Thin films, Borides, Hybrid HiPIMS/DCMS, Hardness, Toughness

\section{INTRODUCTION}

Refractory transition-metal (TM) nitride thin films are employed in a wide variety of applications due to their unique combination of properties including high hardness; ${ }^{1-6}$ scratch and abrasion resistance $;^{7}$ low coefficient of friction ${ }^{8}$ high-temperature oxidation resistance $;^{9-11}$ corrosion resistance; ${ }^{12}$ and tunable optical, electrical, and thermal properties. ${ }^{13-17}$ Recently, TM diborides have been receiving increasing attention as the next generation of refractory, hard ceramic protective thin films for replacing TM nitrides in many applications. ${ }^{18-21} \mathrm{TM}$ diborides are already being employed as coatings on cutting tools ${ }^{22-25}$ and engine components, ${ }^{26-28}$ as well as for use as diffusion barriers in microelectronics. ${ }^{29-31}$ While TM diborides are inherently hard, that alone is not sufficient to prevent failure in applications involving high stresses, since hardness is typically accompanied by brittleness leading to crack formation and propagation. ${ }^{32}$ In order to avoid brittle cracking, thin films must be both hard and relatively ductile. The combination of these 
two properties is referred to as toughness, a measure of the resistance of a material to crack formation.

A common issue in sputter-deposited group-IV TM diborides is that the films often contain excess B. ${ }^{33,34}$ However, it is important to be able to control the $\mathrm{B} / \mathrm{TM}$ ratio, and hence film properties, during deposition. The underlying mechanism leading to the incorporation of excess B in sputter-deposited TM diboride films is the difference in TM and B preferential-ejection angles resulting from mass-mismatch differences between the sputtering gas and the two target constituents. ${ }^{35}$ Increasing the sputtering pressure, and/or the target-to-substrate distance, reduces the TM deficiency due to the higher gas-phase scattering probability of light B atoms during transport to the substrate. ${ }^{35}$ An increase in the substrate bias can also lead to a limited decrease in the $\mathrm{B} / \mathrm{TM}$ ratio as a result of preferential $\mathrm{B}$ resputtering. ${ }^{36}$

A successful approach for obtaining stoichiometric $\mathrm{TiB}_{2}$ films was recently demonstrated by Petrov et al., ${ }^{37}$ who used highly-magnetically-unbalanced magnetron sputtering of a $\mathrm{TiB}_{2}$ target in Ar to selectively ionize sputter-ejected $\mathrm{Ti}$ atoms, which are steered via a tunable external magnetic field to the growing film. The B/Ti ratio was thus controlled by varying the field strength of external Helmholtz coils. Another approach, ${ }^{38}$ also demonstrated for $\mathrm{TiB}_{2}$, but this time using high-power impulse magnetron sputtering (HiPIMS), is to increase the peak current density $\mathbf{J}_{\text {,peak }}$ per pulse by decreasing the HiPIMS pulse length. This results in strongly increased gas rarefaction leading to higher metal-ion densities in the discharge. Film growth then becomes increasingly controlled by ions, rather than neutrals, incident at the substrate. Since sputter-ejected Ti atoms have a higher probability of being ionized than B atoms, due to their lower first-ionization potential $^{39}$ and larger ionization cross-section, ${ }^{40}$ the Ti concentration in films deposited on floating substrates increases, allowing film concentrations to be tuned. 
Here, $\mathrm{ZrB}_{2}$ is employed as a model $\mathrm{TM}$ diboride to demonstrate a novel strategy for simultaneously increasing both hardness and toughness, while also tuning the $\mathrm{B} / \mathrm{TM}$ ratio. $\mathrm{ZrB}_{2}$ has a hexagonal $\mathrm{AlB}_{2}$ crystal structure in which the $\mathrm{B}$ atoms form graphite-like honeycomb sheets between hexagonal-close-packed Zr layers. ${ }^{41}$ The lattice parameters are $3.17 \AA$ in the in-plane adirection and $3.53 \AA$ in the out-of-plane c-direction. ${ }^{41} \mathrm{ZrB}_{2}$, like other TM diborides, but contrary to TM nitrides which have very wide single-phase regions, ${ }^{42,43}$ is a line-compound for which deviations from stoichiometry lead to the formation of second phases. ${ }^{44} \mathrm{ZrB}_{2}$ has a high melting point, $3245{ }^{\circ} \mathrm{C},{ }^{45}$ and a relatively high hardness (reported values range from 19.3 to $45.0 \mathrm{GPa}$ depending primarily upon microstructure, composition, and film stress $)^{44,46-51}$ due to strong covalent bonding between $\mathrm{Zr}$ and $\mathrm{B}$, as well as within the honeycomb B sheets. ${ }^{46}$

We use dc magnetron sputtering (DCMS) from a $\mathrm{ZrB}_{2}$ target in pure Ar to grow $\mathrm{ZrB}_{\mathrm{y}}$ films on $\mathrm{Al}_{2} \mathrm{O}_{3}(0001)$ and $\mathrm{Si}(001)$ substrates at $475^{\circ} \mathrm{C}$ and vary the $\mathrm{TM} / \mathrm{B}$ ratio by adding Ta via pulsed HiPIMS deposition from a Ta target. Pseudobinary $\mathrm{Zr}_{1-\mathrm{x}} \mathrm{Ta}_{\mathrm{x}} \mathrm{B}_{\mathrm{y}}$ alloy layers are deposited by a hybrid HiPIMS/DCMS technique, a method developed by Greczynski et al., ${ }^{52-54}$ with a substrate bias synchronized to the metal-rich portion of each HiPIMS pulse. ${ }^{53-55}$ The B/TM ratio y decreases, while the $\mathrm{Ta} / \mathrm{TM}$ ratio $\mathrm{x}$ increases, continuously from $\mathrm{ZrB}_{2.4}$ to $\mathrm{Zr}_{0.9} \mathrm{Ta}_{0.1} \mathrm{~B}_{2.1}$ to $\mathrm{Zr}_{0.8} \mathrm{Ta}_{0.2} \mathrm{~B}_{1.8}$ to $\mathrm{Zr}_{0.7} \mathrm{Ta}_{0.3} \mathrm{~B}_{1.5}$ with increasing HiPIMS power. All films have the hexagonal $\mathrm{AlB}_{2}$ crystal structure with a dense columnar nanostructure. Film hardnesses increase from $\sim 35.0 \mathrm{GPa}$ for $\mathrm{ZrB}_{2.4}$, with B-rich column boundaries, to $\sim 42.0 \mathrm{GPa}$ for $\mathrm{Zr}_{0.8} \mathrm{Ta}_{0.2} \mathrm{~B}_{1.8}$ and $\mathrm{Zr}_{0.7} \mathrm{Ta}_{0.3} \mathrm{~B}_{1.5}$, with Ta-rich column boundaries, accompanied by a corresponding increase in the nanoindentation toughness from 4.0 to $5.2 \mathrm{MPa} \sqrt{\mathrm{m}}$.

\section{EXPERIMENTAL}


All films are grown in a CC800/9 CemeCon AG sputtering system ${ }^{56}$ equipped with cast rectangular $8.8 \times 50 \mathrm{~cm}^{2}$ stoichiometric $\mathrm{ZrB}_{2}(99.5 \%$ purity, excluding $\mathrm{Hf})$ and elemental $\mathrm{Ta}(99.9 \%$ purity) targets. $\mathrm{Al}_{2} \mathrm{O}_{3}(0001), 1.0 \times 1.0 \mathrm{~cm}^{2}$, and $\mathrm{Si}(001), 1.5 \times 1.5 \mathrm{~cm}^{2}$, substrates are cleaned sequentially in acetone and isopropyl alcohol, and then mounted symmetrically with respect to the targets, which are tilted toward the substrates, resulting in a $21^{\circ}$ angle between the substrate normal and the normal to each target. The $\mathrm{Al}_{2} \mathrm{O}_{3}(0001)$ substrates are used for nanoindentation and residual stress measurements, while the $\mathrm{Si}(001)$ substrates are used for nanostructural studies. The target-to-substrate distance is $18 \mathrm{~cm}$, and the system base pressure is $3.8 \times 10^{-6}$ Torr $(0.5 \mathrm{mPa})$.

The growth chamber is degassed before deposition by applying $8.8 \mathrm{~kW}$ to each of two resistive heaters for $2 \mathrm{~h}$, resulting in a temperature of $475^{\circ} \mathrm{C}$ at the substrate position. The total Ar (99.999\% pure) pressure during deposition is $3 \mathrm{mTorr}(0.4 \mathrm{~Pa})$, and film growth is carried out at $\mathrm{T}_{\mathrm{s}}=475{ }^{\circ} \mathrm{C}$, as measured with a calibrated thermocouple $\mathrm{e}^{57}$ bonded to a dummy substrate coated with $\mathrm{ZrB}_{\mathrm{y}}$. Prior to deposition, the targets are sequentially DCMS etched in Ar at $2 \mathrm{~kW}$ for $60 \mathrm{~s}$ with shutters protecting the substrate table and the opposite target to remove surface oxides and carbon contaminants. A thin continuous Ta buffer layer, with a thickness of $30 \pm 10 \AA$, is initially deposited on all substrates in order to minimize their influence on film morphological evolution.

$\mathrm{ZrB}_{\mathrm{y}}$ films are grown by DCMS at a target power of $5 \mathrm{~kW}$ and a negative de substrate bias of $100 \mathrm{~V}$. For $\mathrm{Zr}_{1-\mathrm{x}} \mathrm{Ta}_{\mathrm{x}} \mathrm{B}_{\mathrm{y}}$ film growth, a hybrid target-power scheme (Ta-HiPIMS/ZrB $2-\mathrm{DCMS}$ ) is employed in which the $\mathrm{ZrB}_{2}$ target is continuously sputtered by DCMS at $5 \mathrm{~kW}$, while the Ta magnetron is operated in HiPIMS mode, with $50 \mu$ s pulses, to supply pulsed $\mathrm{Ta}^{\mathrm{n}+}$ fluxes. A negative substrate potential, $\mathrm{V}_{\mathrm{s}}=100 \mathrm{~V}$, is applied only in synchronous with the $100-\mu$ s metalion-rich portion of each HIPIMS pulse, as determined by time-resolved mass spectroscopy analyses at the substrate position. ${ }^{54}$ The Ta-rich pulse begins at time $t=30 \mu$ s following pulse 
initiation $(t=0)$. At all other times, the substrates are at a negative floating potential, $V_{s}=V_{f}=10$ $\mathrm{V}$. The Ta metal fraction $\mathrm{Ta} /(\mathrm{Zr}+\mathrm{Ta})$ on the cation sublattice is varied from 0.1 to 0.3 by changing the average power $\mathcal{S}_{\text {Ta }}$ applied to the HiPIMS Ta target from 0 to 600 to 1200 to $1800 \mathrm{~W}$, while the pulsing frequency fis increased from 0 to 100 to 200 to $300 \mathrm{~Hz}$. Thus, the energy per pulse is maintained constant at $6 \mathrm{~J}$, resulting in a constant Ta-target peak current density per HiPIMS pulse $\mathrm{J}_{\mathrm{T}, \text { peak }}$ of $0.71 \pm 0.03 \mathrm{~A} / \mathrm{cm}^{2}$. Film deposition rates are $9 \AA / \mathrm{s}$ for $\mathrm{ZrB}_{2.4}$ and $\sim 10 \AA / \mathrm{s}$ for $\mathrm{Zr}_{1-\mathrm{x}} \mathrm{Ta}_{\mathrm{x}} \mathrm{B}_{\mathrm{y}}$.

A Hiden Analytical EQP1000 instrument is utilized to perform in-situ time-resolved analyses of ion fluxes incident at the substrate plane under the same conditions as during film deposition. The orifice of the spectrometer is placed at the substrate position, facing the target center. Data are recorded during 100 consecutive HiPIMS pulses such that the total acquisition time per data point is $1 \mathrm{~ms}$. Additional details regarding the measurements are given in Ref. 58. A Tektronix $500 \mathrm{MHz}$ digital oscilloscope is used to measure target current and voltage waveforms.

Substrate wafer curvature measurements are employed, based on the modified Stoney equation, ${ }^{59,60}$

$$
\sigma_{f}=\left(M_{s} h_{s}^{2}\right) /\left(6 R_{s} h_{f}\right),
$$

to determine the in-plane residual stress of layers grown on $\mathrm{Al}_{2} \mathrm{O}_{3}(0001) . \sigma_{f}$ in Eq.(1) is the average biaxial stress; $h_{f}$ and $h_{s}$ are film and substrate thicknesses, respectively; $R_{s}$ is the substrate radius of curvature; and $M_{S}$ is the substrate biaxial modulus (602 GPa). ${ }^{61}$ Substrate curvatures are determined before and after film deposition from rocking-curve measurements carried out in a PANalytical Empyrean high-resolution x-ray diffractometer operated at $45 \mathrm{kV}$ and $40 \mathrm{~mA}$. Reported $\sigma_{f}$ values are corrected for thermal stresses $\sigma_{\text {th }}$ due to cooling the samples from $\mathrm{T}_{\mathrm{s}}$ to room temperature, $\Delta \mathrm{T}=450 \mathrm{~K} .{ }^{62}$ The thermal expansion coefficient $\alpha_{\mathrm{s}}$ of $\mathrm{Al}_{2} \mathrm{O}_{3}$ is $8.1 \times 10^{-6} \mathrm{~K}^{-1}{ }^{163}$ For $\mathrm{Zr}_{1-\mathrm{x}} \mathrm{Ta}_{\mathrm{x}} \mathrm{B}_{\mathrm{y}}$ alloys, $\alpha_{\mathrm{f}}$ is estimated based upon a linear extrapolation between the thermal 
expansion coefficient for $\mathrm{ZrB}_{2}\left(5.3 \times 10^{-6} \mathrm{~K}^{-1}\right)^{64}$ and that of $\mathrm{TaB}_{2}\left(8.2 \times 10^{-6} \mathrm{~K}^{-1}\right),{ }^{65}$ and we use elastic moduli determined by nanoindentation (see Fig. 9). $\sigma_{\text {th }}$ decreases from -707 MPa for $\mathrm{ZrB}_{2.4}$, to $647 \mathrm{MPa}$ for $\mathrm{Zr}_{0.9} \mathrm{Ta}_{0.1} \mathrm{~B}_{2.1}$, to -589 MPa for $\mathrm{Zr}_{0.8} \mathrm{Ta}_{0.2} \mathrm{~B}_{1.8}$, and -502 for $\mathrm{Zr}_{0.7} \mathrm{Ta}_{0.3} \mathrm{~B}_{1.5}$.

A Zeiss LEO 1550 scanning electron microscope (SEM) is used to obtain film thicknesses and morphologies from fracture cross sections. Deposition times are adjusted based upon calibration curves such that all films are 1.6- $\mu$ m thick. $\theta-2 \theta$ x-ray diffraction (XRD) scans are carried out using a Philips $X^{\prime}$ Pert $x$-ray diffractometer with a $\mathrm{Cu} \mathrm{K}_{\alpha}$ source $(\lambda=1.5406 \AA)$ to determine crystal structure and orientation. Film compositions are obtained from time-of-flight elastic recoil detection analyses (ToF-ERDA) carried out in a tandem accelerator with a $36 \mathrm{MeV}$ ${ }^{127} \mathrm{I}^{8+}$ probe beam incident at $67.5^{\circ}$ with respect to the sample surface normal; recoils are detected at $45^{\circ}$.

Chemical bonding in the $\mathrm{Zr}_{1-\mathrm{x}} \mathrm{Ta}_{\mathrm{x}} \mathrm{B}_{\mathrm{y}}$ films is evaluated by $\mathrm{x}$-ray photoelectron spectroscopy (XPS) using a Kratos Axis Ultra DLD instrument employing monochromatic $\mathrm{Al} \mathrm{K}_{\alpha}$ radiation (hv $=1486.6 \mathrm{eV})$. Surface contamination resulting from sample air exposure is first removed by sputter-etching the films for $120 \mathrm{~s}$ with a $4 \mathrm{keV} \mathrm{Ar}^{+}$ion beam incident at $70^{\circ}$ with respect to the sample normal; the $\mathrm{Ar}^{+}$ion energy is then reduced to $0.5 \mathrm{keV}$ for $600 \mathrm{~s}$ to minimize surface damage. ${ }^{66}$ Sample areas analyzed by XPS are $0.3 \times 0.7 \mathrm{~mm}^{2}$ and located in the center of $3 \times 3 \mathrm{~mm}^{2}$ ion-etched regions. The binding energy scale is calibrated using an ISO-certified procedure ${ }^{67}$ to avoid uncertainties associated with employing the $\mathrm{C} 1 \mathrm{~s}$ peak from adventitious carbon. ${ }^{68}$

Cross-sectional and plan-view transmission electron microscopy (TEM) analyses are carried out in an FEI Titan ${ }^{3}$ 60-300 instrument operated at $300 \mathrm{kV}$; Z-contrast images are acquired in scanning TEM (STEM) mode. Energy-dispersive x-ray (EDX) and electron energy-loss spectroscopy (EELS) elemental maps are also obtained with the FEI instrument. Cross-sectional 
TEM (XTEM) specimens are prepared by mechanical polishing, followed by $\mathrm{Ar}^{+}$ion milling at 5 $\mathrm{keV}$, with a $3^{\circ}$ incidence angle, on both sides of each sample during rotation, in a Gatan precision ion miller. For the final stages of sample thinning, the ion energy is reduced to $2.5 \mathrm{keV}$. Plan-view specimens are prepared following the same approach except that the samples are ion milled only from the substrate side.

Atom probe tomography (APT) specimens are prepared using the lift-off protocol ${ }^{69}$ in a Zeiss 1540EsB CrossBeam focused ion beam (FIB) system operated with $\mathrm{Ga}^{+}$ions at $30 \mathrm{keV}$, which is reduced to $5 \mathrm{keV}$ during the final ion-etching step until the protective Pt cap layer is removed..$^{70}$ The APT specimens are analyzed using an Imago Local Electrode Atom Probe (LEAP) 3000X HR system in ultra-high vacuum conditions with either laser or voltage pulsing. The typical results shown here are imaged in the voltage-pulsing mode with a frequency of $200 \mathrm{kHz}, \mathrm{a}$ maximum pulse voltage that is $15 \%$ of the dc voltage, and a sample temperature of $-193{ }^{\circ} \mathrm{C}$. The total applied voltage (dc plus pulsed) is continuously adjusted to maintain an $\sim 0.1 \%$ fieldevaporation probability from each pulse. The APT reconstructions are obtained following the procedure of Geiser et al. ${ }^{71}$ and the parameters are validated using SEM measurements of the initial and final shank angles and radii of curvature, as well as lattice traces in the 0001 direction.

Nanoindentation analyses of $\mathrm{Zr}_{1-\mathrm{x}} \mathrm{Ta}_{\mathrm{x}} \mathrm{B}_{\mathrm{y}}$ layers grown on $\mathrm{Al}_{2} \mathrm{O}_{3}(0001)$ substrates are performed in an Ultra-Micro Indentation System (UMIS) with a sharp Berkovich diamond tip calibrated using a fused-silica standard and a single-crystal stoichiometric $\operatorname{TiN}(001)$ reference sample. ${ }^{72}$ For hardness $\mathrm{H}$ measurements, the load $\mathrm{P}$ is increased from 3 to $27 \mathrm{mN}$ at increments of $0.5 \mathrm{mN}$, and the results analyzed using the Oliver and Pharr method. ${ }^{73}$ Indents to depths $\geq 10 \%$ of the film thickness are excluded in the analysis. Reported $\mathrm{H}$ values are the average of the remaining results, typically 10 indents per sample. Indentation elastic moduli $\mathrm{E}$ are determined by applying 
a fixed load, corresponding to the plateau in the $\mathrm{H}$ vs. P plot for each sample. The Poisson ratio $v$ is required in order to obtain $\mathrm{E}$. For $\mathrm{ZrB}_{2}, v=0.13^{74}$. Poisson ratio values for $\mathrm{Zr}_{1-\mathrm{x}} \mathrm{Ta}_{\mathrm{x}} \mathrm{B}_{\mathrm{y}}$ alloys are unknown and estimated based upon a linear extrapolation between the Poisson ratio of $\mathrm{ZrB}_{2}$ and that of $\mathrm{TaB}_{2}(0.21) \cdot{ }^{75,76}$ Uncertainties introduced in reported $\mathrm{E}$ values due to this approximation are less than $1 \%$.

Film nanoindentation toughnesses $\mathrm{K}_{\mathrm{c}}$ are estimated, following the approach of Lawn et al., ${ }^{77}$ by measuring average lengths of radial cracks around sample indents produced with a diamond cube-corner tip over a load range from 10 to $50 \mathrm{mN}$. Three indents are made at each load. Cube-corner tips are sharper and provide much higher local stresses than Berkovich tips.

\section{RESULTS AND DISCUSSION}

\section{A. Results}

Time-dependent intensities of energy-integrated $\mathrm{Ta}^{+}, \mathrm{Ta}^{2+}$, and $\mathrm{Ar}^{+}$ion fluxes incident at the substrate plane during and after $50-\mu$ s HiPIMS pulses with a Ta target power $\mathcal{P}_{\mathrm{Ta}}=1800 \mathrm{~W}$ and peak current density $\mathrm{J}_{\mathrm{T} \text {,peak }}=0.71 \pm 0.03 \mathrm{~A} / \mathrm{cm}^{2}$, are plotted in Fig. 1 with a $10-\mu$ s resolution. During the time in which the synchronized substrate bias is applied, 30 to $130 \mu$ s following HiPIMS pulse initiation, the integrated $\mathrm{Ta}^{+}$intensity constitutes $91 \%$ of the total ion flux, while $\mathrm{Ta}^{2+}$ and $\mathrm{Ar}^{+}$contribute 5 and $4 \%$, respectively. The dominance of the $\mathrm{Ta}^{+}$signal is due primarily to strong gas rarefaction, ${ }^{78,79}$ together with quenching of the electron-energy distribution ${ }^{80}$ due to the fact that the first ionization potential of $\mathrm{Ta}(7.55 \mathrm{eV})$ is lower than both the first ionization potential of $\operatorname{Ar}(15.76 \mathrm{eV})$ and the second Ta ionization potential $(16.17 \mathrm{eV}) .{ }^{39}$ The Ar second ionization potential is $25.6 \mathrm{eV} ;{ }^{39}$ thus, the $\mathrm{Ar}^{2+}$ intensity is negligible. $\mathrm{The}^{2+} \mathrm{Ta}^{2+}\left(\mathrm{Ta}^{+}+\mathrm{Ta}^{2+}\right)$ ratio during the $100-\mu$ s synchronized substrate bias is 0.052 . 


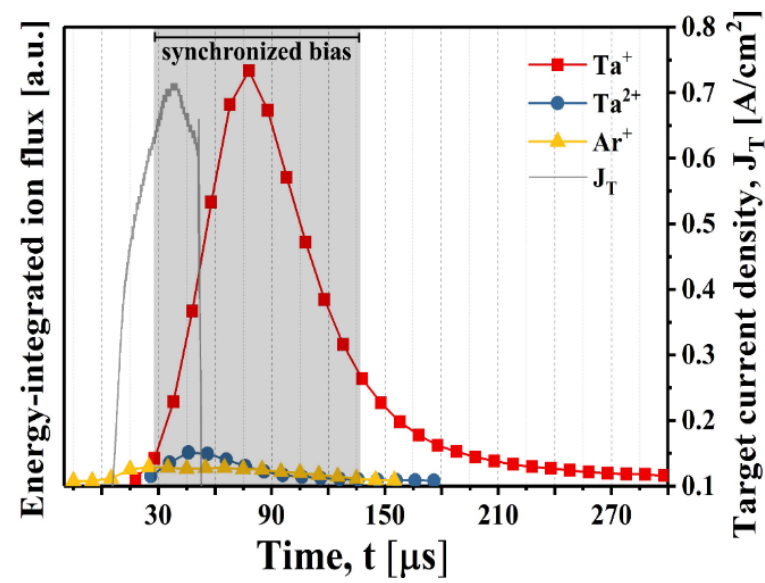

Fig. 1. Time evolution of energy-integrated $\mathrm{Ta}^{+}, \mathrm{Ta}^{2+}$, and $\mathrm{Ar}^{+}$ion fluxes incident at the substrate plane during and after a $50-\mu$ s Ta-HiPIMS pulse in which the Ta target is sputtered at $1800 \mathrm{~W}$ in pure Ar at 3 mTorr. The continuous grey line, with no data symbols, is the target current density $J_{T}$ as a function of time $t$; the peak current density $J_{T \text {,peak }}$ is $0.71 \pm 0.03 \mathrm{~A} / \mathrm{cm}^{2}$. A negative substrate bias $\mathrm{V}_{\mathrm{s}}=100 \mathrm{~V}$ is applied in synchronous with the Ta-ion-rich portions of each HiPIMS pulse. Data points at time t correspond to the number of ions collected during the interval from ( $t$ 5) to $(\mathrm{t}+5) \mu \mathrm{s}$.

$\mathrm{Zr}_{1-\mathrm{x}} \mathrm{Ta}_{\mathrm{x}} \mathrm{B}_{\mathrm{y}}$ film compositions, determined by ToF-ERDA, for layers grown at $\mathcal{P}_{\mathrm{Ta}}$ values from 0 to $1800 \mathrm{~W}$ are listed in Table $1 . \mathrm{ZrB}_{\mathrm{y}}$ films deposited using $\mathrm{DCMS}\left(\mathscr{P}_{\mathrm{Ta}}=0\right)$ are overstoichiometric with $y=2.4$. Alloy films grown by hybrid Ta-HiPIMS/ZrB2-DCMS have $\mathrm{x}$ values which increase from 0.1 with $\mathcal{P}_{\mathrm{Ta}}=600 \mathrm{~W}$, to 0.2 for $\mathcal{P}_{\mathrm{Ta}}=1200 \mathrm{~W}$, to 0.3 at $\mathcal{P}_{\mathrm{Ta}}=1800 \mathrm{~W}$. Concurrently, y decreases from 2.1 to 1.8 to 1.5 as a function of $\mathcal{P}_{\text {Ta }}$. Carbon, nitrogen, and oxygen concentrations are below detection limits, $\sim 0.1$ at $\%$, and Ar concentrations are $\leq 0.5$ at $\%$ for all films. 
Table 1. ToF-ERDA elemental compositions, with experimental uncertainties $<0.01$, of $\mathrm{Zr}_{1-}$ ${ }_{x} \mathrm{Ta}_{\mathrm{x}} \mathrm{B}_{\mathrm{y}}$ films grown on $\mathrm{Si}(001)$ substrates at $475{ }^{\circ} \mathrm{C}$ in pure $\mathrm{Ar}$ (3 mTorr) by hybrid TaHiPIMS/ZrB 2 -DCMS, with 50- $\mu$ s HiPIMS pulses, as a function of increasing Ta target power $\mathcal{P}_{\text {Ta }}$ and pulse frequency $\mathrm{f}$. A negative substrate bias $\mathrm{V}_{\mathrm{s}}=100 \mathrm{~V}$ is applied in synchronous with the Taion-rich portion of each pulse.

\begin{tabular}{cccc}
\hline $\mathcal{P}_{\mathrm{Ta}}[\mathrm{W}]$ & $\mathrm{f}[\mathrm{Hz}]$ & $\mathrm{x}$ & $\mathrm{y}$ \\
\hline 0 & 0 & 0 & 2.4 \\
600 & 100 & 0.1 & 2.1 \\
1200 & 200 & 0.2 & 1.8 \\
1800 & 300 & 0.3 & 1.5 \\
\hline
\end{tabular}

XRD $\theta-2 \theta$ scans from as-deposited $\mathrm{Zr}_{1-\mathrm{x}} \mathrm{Ta}_{\mathrm{x}} \mathrm{B}_{\mathrm{y}}$ films grown on $\mathrm{Si}(001)$ substrates are shown in Fig. 2. Vertical solid and dashed lines correspond to reference powder-diffraction peak positions for $\mathrm{ZrB}_{2}{ }^{41}$ and $\mathrm{TaB}_{2},{ }^{81}$ respectively. The peak at $32.8^{\circ}$ arises from the forbidden $002 \mathrm{Si}(001)$ substrate reflection due to multiple scattering. ${ }^{82}$ All other peaks originate from hexagonal-structure $\mathrm{Zr}_{1-\mathrm{x}} \mathrm{Ta}_{\mathrm{x}} \mathrm{B}_{\mathrm{y}}$. The 0001 and 0002 reflections shift toward higher $2 \theta$ values with increasing $\mathrm{x}$, corresponding to a decrease in the out-of-plane c lattice parameter from $3.54 \AA$ for $\mathrm{ZrB}_{2.4}$ and $\mathrm{Zr}_{0.7} \mathrm{Ta}_{0.3} \mathrm{~B}_{2.1}$ to $3.49 \AA$ for $\mathrm{Zr}_{0.8} \mathrm{Ta}_{0.2} \mathrm{~B}_{1.8}$ and $3.48 \AA$ for $\mathrm{Zr}_{0.7} \mathrm{Ta}_{0.3} \mathrm{~B}_{1.5}$, as a result of the replacement of $\mathrm{Zr}$ by Ta atoms with a smaller covalent radius, ${ }^{83}$ the corresponding lower B concentrations, ${ }^{84}$ and film compressive stress (see below). All $000 \mathrm{l}$ peaks broaden with increasing Ta concentrations on the cation sublattice. The full-width at half-maximum (FWHM) intensity of the 0001 reflection is $0.4^{\circ}$ with $\mathrm{x}=0,0.63^{\circ}$ at $\mathrm{x}=0.2,1.16^{\circ}$ at $\mathrm{x}=0.3$, and $1.28^{\circ}$ with $\mathrm{x}=0.3 . \mathrm{Zr}_{0.8} \mathrm{Ta}_{0.2} \mathrm{~B}_{1.8}$ and $\mathrm{Zr}_{0.7} \mathrm{Ta}_{0.3} \mathrm{~B}_{1.5} 000 l$ peaks are asymmetric toward higher $2 \theta$ values, an indication that $\mathrm{Ta}_{\mathrm{x}} \mathrm{B}_{\mathrm{y}}$ is not distributed uniformly. Intensities of $10 \overline{1} 0,10 \overline{1} 1,11 \overline{2} 0,10 \overline{1} 2$, and $11 \overline{2} 1$ reflections decrease with increasing $\mathrm{x}$ and are not detectable in alloy films with $\mathrm{x} \geq 0.2$. Film preferred orientation changes from weak $10 \overline{1} 1$ for $\mathrm{ZrB}_{2.4}$ to 0001 for $\mathrm{Zr}_{0.7} \mathrm{Ta}_{0.3} \mathrm{~B}_{1.5}$, as determined from relative texture 
coefficients $R T C_{h k i l}=I_{h k i l} / \sum I_{h k i l},{ }^{41,81,85}$ for which $I_{h k i l}$ is the intensity of hkil reflections normalized to their powder-pattern values. $R T C_{10 \overline{1} 1}$ ranges from 0.32 for $\mathrm{ZrB}_{2.4}$, to 0.27 for $\mathrm{Zr}_{0.9} \mathrm{Ta}_{0.1} \mathrm{~B}_{2.1}, 0.04$ for $\mathrm{Zr}_{0.8} \mathrm{Ta}_{0.2} \mathrm{~B}_{1.8}$, and 0 for $\mathrm{Zr}_{0.7} \mathrm{Ta}_{0.3} \mathrm{~B}_{1.5}$, while $R T C_{0001}$ increases from 0.15 to $0.19,0.52$, and 0.55 .

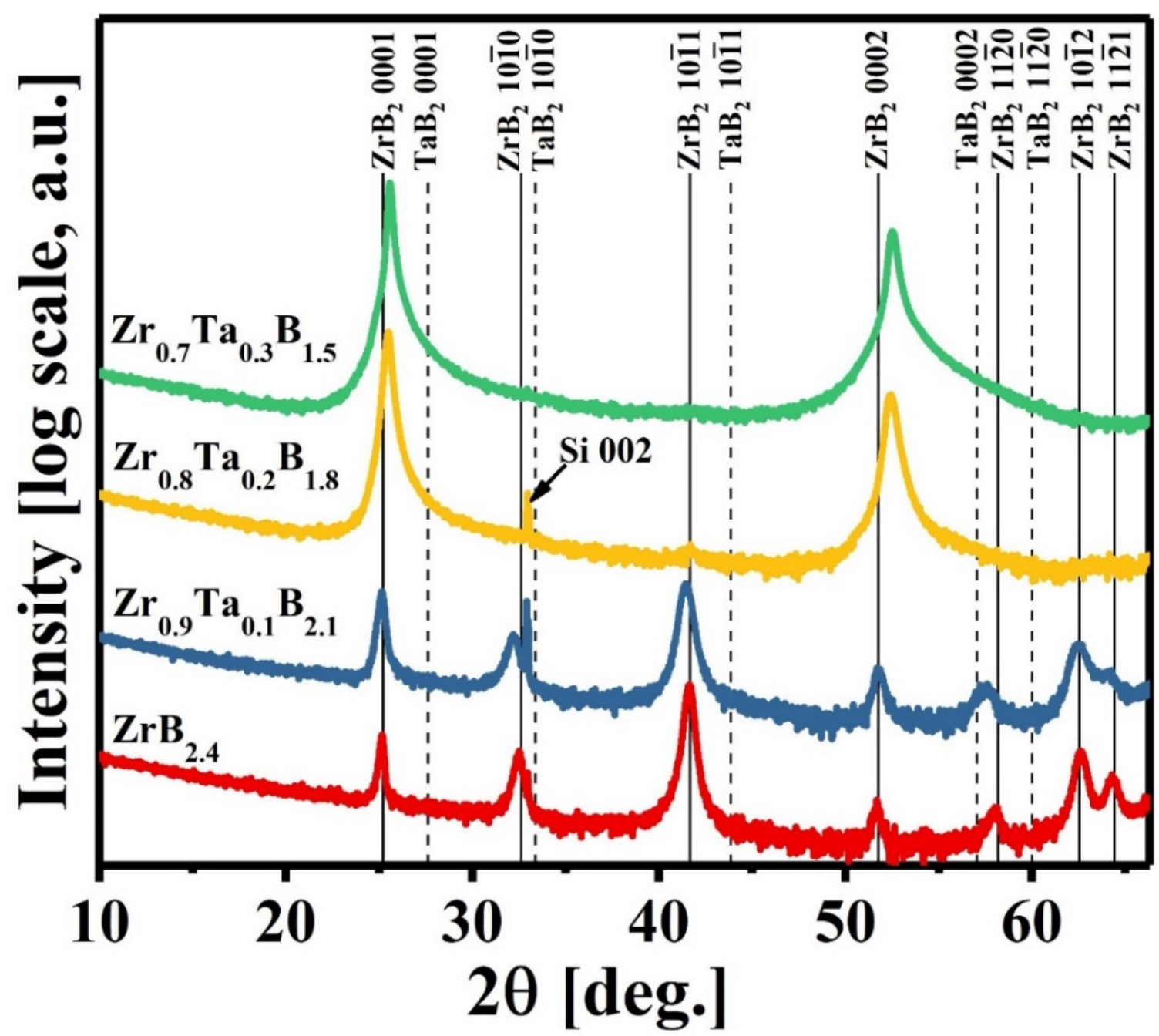

Fig. 2. XRD $\theta-2 \theta$ scans from $\mathrm{Zr}_{1-\mathrm{x}} \mathrm{Ta}_{\mathrm{x}} \mathrm{B}_{\mathrm{y}}$ films grown on $\mathrm{Si}(001)$ at $475{ }^{\circ} \mathrm{C}$ in pure $\mathrm{Ar}(3$ mTorr) by hybrid Ta-HiPIMS/ZrB 2 -DCMS, with $50-\mu$ s HiPIMS pulses, as a function of increasing Ta target power $\mathscr{P}_{\text {Ta }}$. A negative substrate bias $\mathrm{V}_{\mathrm{s}}=100 \mathrm{~V}$ is applied in synchronous with the Taion-rich portion of each pulse. 
Fig. 3 consists of cross-sectional SEM (XSEM) images of the $\mathrm{Zr}_{1-\mathrm{x}} \mathrm{Ta}_{\mathrm{x}} \mathrm{B}_{\mathrm{y}}$ films corresponding to Fig. 2, together with inset bright-field XTEM images and selected-area electron diffraction (SAED) patterns; the latter are obtained from areas in upper film regions. The XSEM images show that the films have dense, columnar structures with smooth surfaces. XTEM micrographs reveal columnar growth with no discernable porosity. The reflections in the $\mathrm{ZrB}_{2.4}$ SAED pattern consist of broad arcs, while the patterns from alloy films grown with Ta-ion bombardment exhibit pronounced 0001 fiber textures with increasingly strong preferred orientation, consistent with the XRD results.

(a) $\mathrm{ZrB}_{2.4}$

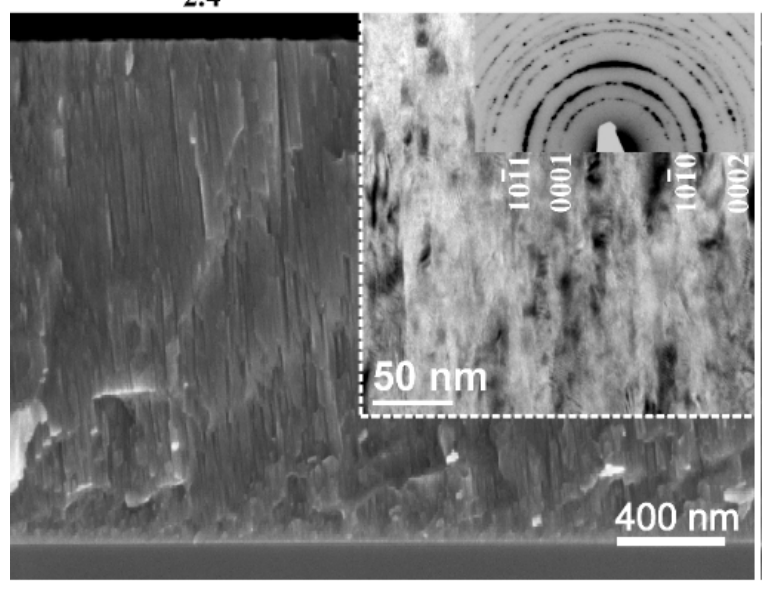

(c) $\mathrm{Zr}_{0.8} \mathrm{Ta}_{0.2} \mathrm{~B}_{1.8}$

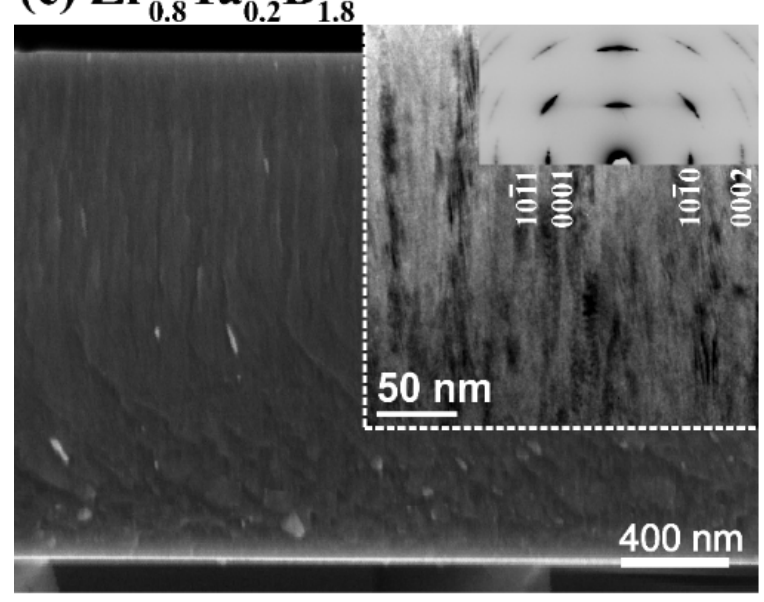

(b) $\mathrm{Zr}_{0.9} \mathrm{Ta}_{0.1} \mathrm{~B}_{2.1}$

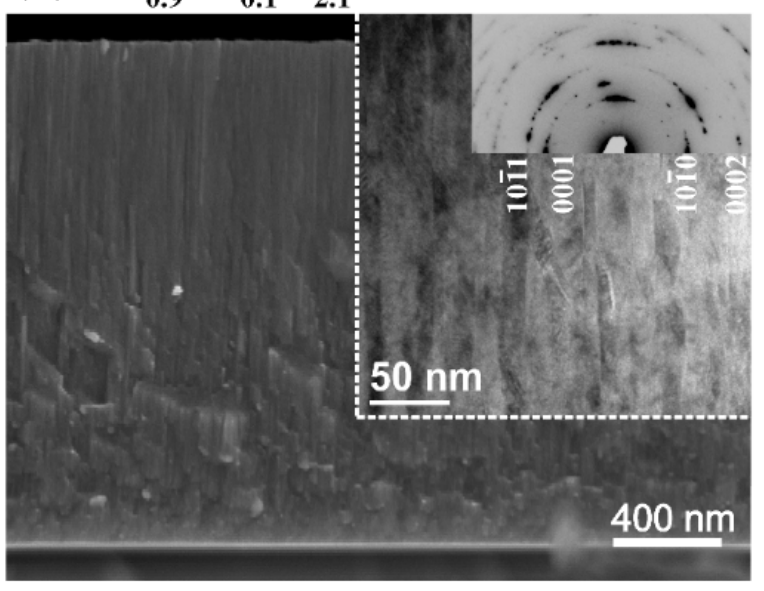

(d) $\mathrm{Zr}_{0.7} \mathrm{Ta}_{0.3} \mathrm{~B}_{1.5}$

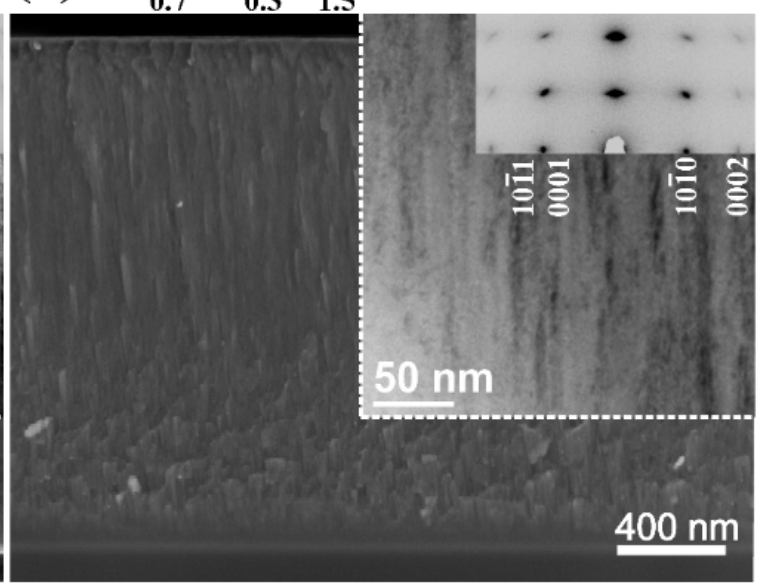


Fig. 3. Typical XSEM images, with inset bright-field XTEM images and SAED patterns, from (a) $\mathrm{ZrB}_{2.4}$, (b) $\mathrm{Zr}_{0.9} \mathrm{Ta}_{0.1} \mathrm{~B}_{2.1}$, (c) $\mathrm{Zr}_{0.8} \mathrm{Ta}_{0.2} \mathrm{~B}_{1.8}$, and (d) $\mathrm{Zr}_{0.7} \mathrm{Ta}_{0.3} \mathrm{~B}_{1.5}$ films grown on $\mathrm{Si}(001)$ at $475^{\circ} \mathrm{C}$ in pure $\mathrm{Ar}$ (3 mTorr) by hybrid Ta-HiPIMS/ZrB 2 -DCMS, with $50-\mu$ s HiPIMS pulses, as a function of increasing Ta target power $\mathcal{P}_{\text {Ta }}$. A negative substrate bias $\mathrm{V}_{\mathrm{s}}=100 \mathrm{~V}$ is applied in synchronous with the Ta-ion-rich portion of each pulse.

Bright-field $\mathrm{Zr}_{1-\mathrm{x}} \mathrm{Ta}_{\mathrm{x}} \mathrm{B}_{\mathrm{y}}$ plan-view TEM images are shown in Fig. 4. Average column widths increase from $90 \pm 20 \AA$ for $\mathrm{ZrB}_{2.4}$ to $320 \pm 130 \AA$ for $\mathrm{Zr}_{0.9} \mathrm{Ta}_{0.1} \mathrm{~B}_{2.1}$ films, and then decrease to $110 \pm 30 \AA$ for $\mathrm{Zr}_{0.8} \mathrm{Ta}_{0.2} \mathrm{~B}_{1.8}$, and $80 \pm 30 \AA$ for $\mathrm{Zr}_{0.7} \mathrm{Ta}_{0.3} \mathrm{~B}_{1.5}$. The corresponding SAED patterns in the insets are consistent with the results in Figs. 2 and 3 showing that the out-of-plane preferred orientation increases to a strong 0001 (characterized by a dominant $10 \overline{1} 0$ reflection in plan-view) for films with increasing Ta concentrations on the cation sublattice. In addition, plan-view STEM images, shown as insets in Fig. 4, reveal a change in contrast at the column boundaries as a function of $\mathrm{x} ; \mathrm{ZrB}_{2.4}$ and $\mathrm{Zr}_{0.9} \mathrm{Ta}_{0.1} \mathrm{~B}_{2.1}$ column boundaries appear dark, indicating a lower average mass than that of the adjacent columns, while the $\mathrm{Zr}_{0.8} \mathrm{Ta}_{0.2} \mathrm{~B}_{1.8}$ and $\mathrm{Zr}_{0.7} \mathrm{Ta}_{0.3} \mathrm{~B}_{1.5}$ column boundaries exhibit a bright, higher mass, contrast. 

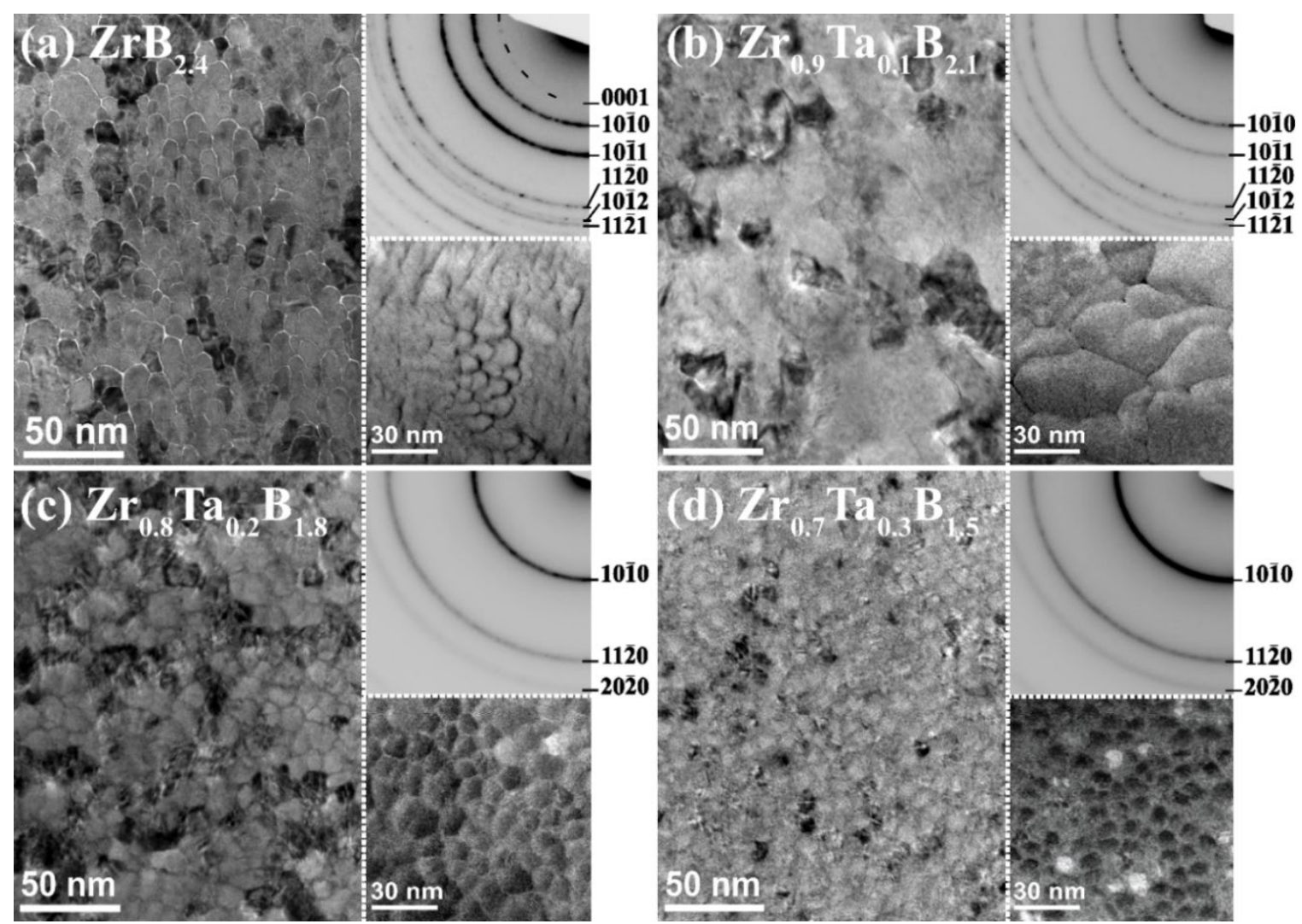

Fig. 4. Plan-view TEM images, with corresponding SAED patterns and plan-view STEM images as insets, of (a) $\mathrm{ZrB}_{2.4}$, (b) $\mathrm{Zr}_{0.9} \mathrm{Ta}_{0.1} \mathrm{~B}_{2.1}$, (c) $\mathrm{Zr}_{0.8} \mathrm{Ta}_{0.2} \mathrm{~B}_{1.8}$, and (d) $\mathrm{Zr}_{0.7} \mathrm{Ta}_{0.3} \mathrm{~B}_{1.5}$ films grown on $\mathrm{Si}(001)$ at $475^{\circ} \mathrm{C}$ in pure $\mathrm{Ar}(3 \mathrm{mTorr})$ by hybrid Ta-HiPIMS/ZrB 2 -DCMS, with $50-\mu$ s HiPIMS pulses, as a function of increasing Ta target power $\mathcal{P}_{\text {Ta }}$. A negative substrate bias $\mathrm{V}_{\mathrm{s}}=100 \mathrm{~V}$ is applied in synchronous with the Ta-ion-rich portion of each pulse.

Fig. 5 is comprised of typical STEM Z-contrast plan-view images, with corresponding EDX and EELS elemental maps, of $\mathrm{ZrB}_{2.4}$ and $\mathrm{Zr}_{0.8} \mathrm{Ta}_{0.2} \mathrm{~B}_{1.8}$ films. The dark regions in the Zcontrast image of $\mathrm{ZrB}_{2.4}$, Fig. 5(a), correspond to low-Z (i.e., B-rich) column-boundary areas as reported previously by Mayrhofer et al. for overstoichiometric $\mathrm{TiB}_{2.4}$ layers grown by unbalanced magnetron sputtering. ${ }^{86}$ The Zr EDX map in Fig. 5(b) reveals, in agreement with the results in Fig. 5(a), that the dark areas in the $\mathrm{ZrB}_{2.4} \mathrm{Z}$-contrast image are $\mathrm{Zr}$ deficient, while the corresponding 
EELS spectra in Fig. 5(c) confirm that the column boundaries are B rich. In contradistinction to $\mathrm{ZrB}_{2.4}$, the Z-contrast image of $\mathrm{Zr}_{0.8} \mathrm{Ta}_{0.2} \mathrm{~B}_{1.8}$ in Fig. 5(d) reveals boundaries with lighter contrast, indicating enrichment with heavier elements. Complementary EDX Zr and Ta elemental maps, Fig. 5(e), show that the amount of Ta at column boundaries is significantly higher than in the columns. The EELS spectra in Fig. 5(f) affirm that $\mathrm{Zr}_{0.8} \mathrm{Ta}_{0.2} \mathrm{~B}_{1.8}$ column boundaries are B deficient with respect to the columns. Thus, increasing the Ta cation concentration in $\mathrm{Zr}_{1-\mathrm{x}} \mathrm{Ta}_{\mathrm{x}} \mathrm{B}_{\mathrm{y}}$ films changes the column boundaries from being B-rich to Ta-rich. Results for $\mathrm{Zr}_{0.9} \mathrm{Ta}_{0.1} \mathrm{~B}_{2.1}$ and $\mathrm{Zr}_{0.7} \mathrm{Ta}_{0.3} \mathrm{~B}_{1.5}$ films reveal structures similar to those of $\mathrm{ZrB}_{2.4}$ and $\mathrm{Zr}_{0.8} \mathrm{Ta}_{0.2} \mathrm{~B}_{1.8}$ with B-rich and Ta-rich boundaries, respectively.
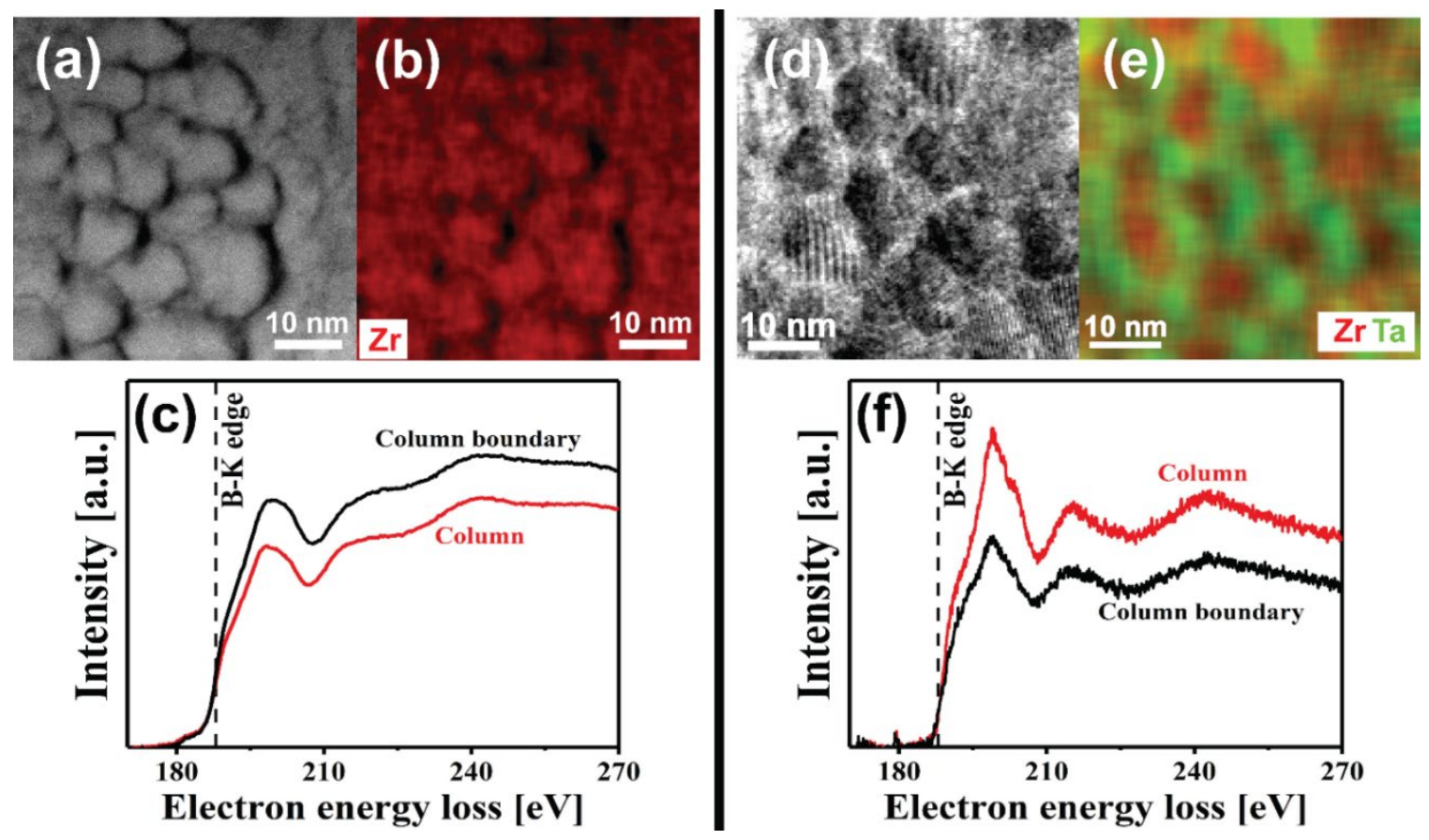

Fig. 5. Plan-view (a) STEM Z-contrast image and (b) Zr EDX map with (c) corresponding EELS spectra from columns and column boundaries for $\mathrm{ZrB}_{2.4}$ grown by DCMS. (d) Plan-view STEM Z-contrast image, and (e) EDX TM elemental maps with (f) corresponding EELS spectra from columns and column boundaries for $\mathrm{Zr}_{0.8} \mathrm{Ta}_{0.2} \mathrm{~B}_{1.8}$ films grown by hybrid Ta-HiPIMS/ZrB 2 DCMS, with $50-\mu$ s HiPIMS pulses, at $\mathscr{P}_{\mathrm{Ta}}=1200 \mathrm{~W}$. A negative substrate bias $\mathrm{V}_{\mathrm{s}}=100 \mathrm{~V}$ is 
applied in synchronous with the Ta-ion-rich portion of each pulse. The films are grown on $\operatorname{Si}(001)$ at $475{ }^{\circ} \mathrm{C}$ in pure $\operatorname{Ar}(3 \mathrm{mTorr})$.

APT is also used to probe compositional differences between columns and their adjacent boundaries. $\mathrm{Zr}_{0.8} \mathrm{Ta}_{0.2} \mathrm{~B}_{1.8}$ films are selected for analysis since, based on the STEM Z-contrast micrographs in Fig. 4, they have slightly wider columns than $\mathrm{Zr}_{0.7} \mathrm{Ta}_{0.3} \mathrm{~B}_{1.5}$ layers. A twodimensional map of the $\mathrm{Ta} /(\mathrm{Zr}+\mathrm{Ta})$ fraction in a $30-\AA$-thick $\mathrm{Zr}_{0.8} \mathrm{Ta}_{0.2} \mathrm{~B}_{1.8}$ slab containing a portion of a typical column, with adjacent boundaries, along the film growth direction is shown in Fig. 6(a). The boundary regions are Ta rich and thus appear darker in the two-dimensional map. The column is $\sim 120$ - $\AA$ wide, in good agreement with Z-contrast images in Figs. 4 and 5. Fig. 6(b) is a typical $\mathrm{Ta} /(\mathrm{Zr}+\mathrm{Ta})$ profile across the region in Fig. $6(\mathrm{a})$ highlighted by the $30 \times 30 \mathrm{~cm}^{2}$ black square. APT artifacts, including trajectory aberrations,${ }^{87}$ induce a very small spatial mismatch between the $\mathrm{Ta}$ and $\mathrm{Zr}$ signals that broadens the boundary regions and may also cause the $\mathrm{Ta} /(\mathrm{Zr}+\mathrm{Ta})$ fraction to be slightly underestimated in the column boundaries. Overall, the APT data is in agreement with STEM analysis and shows that the column boundaries of $\mathrm{Zr}_{0.8} \mathrm{Ta}_{0.2} \mathrm{~B}_{1.8}$ layers are metal-rich, with a higher Ta concentration, compared to the columnar grains. 


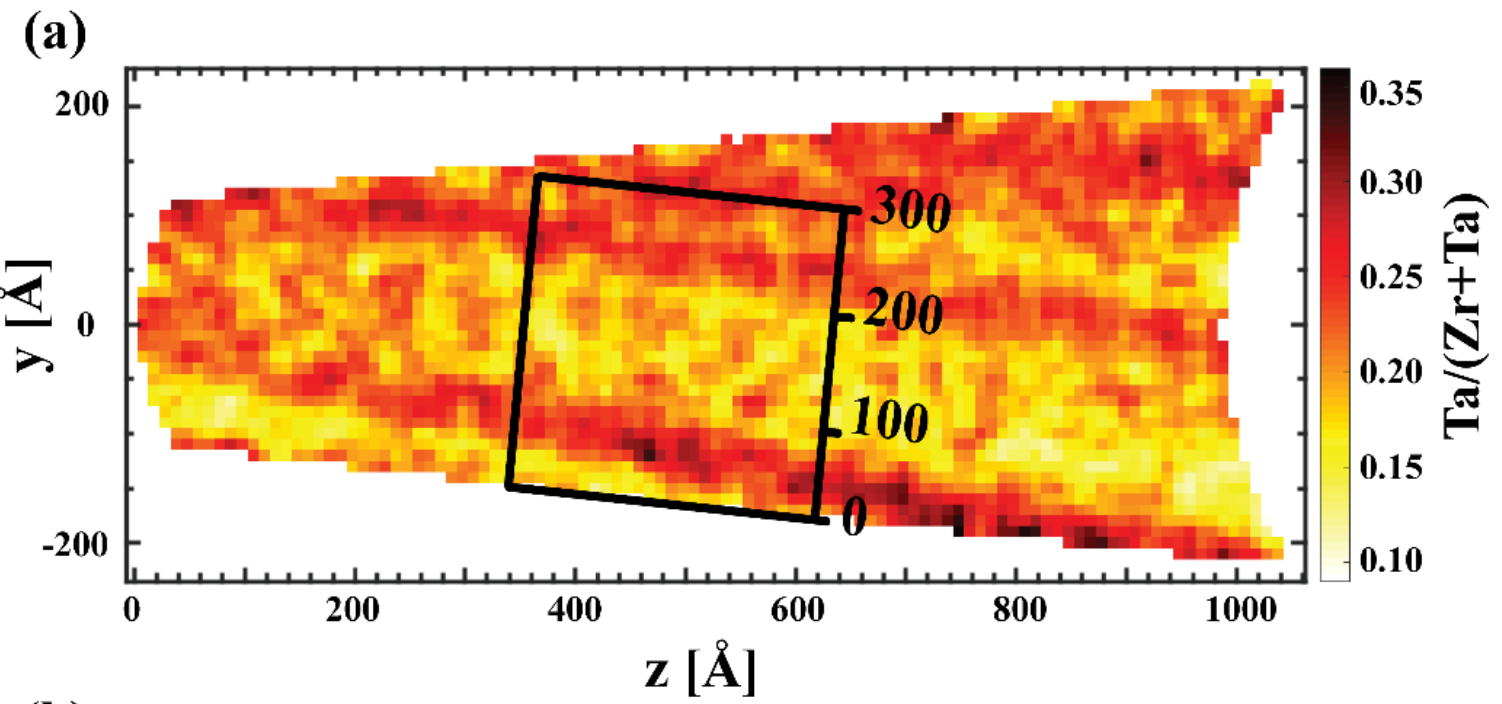

(b)

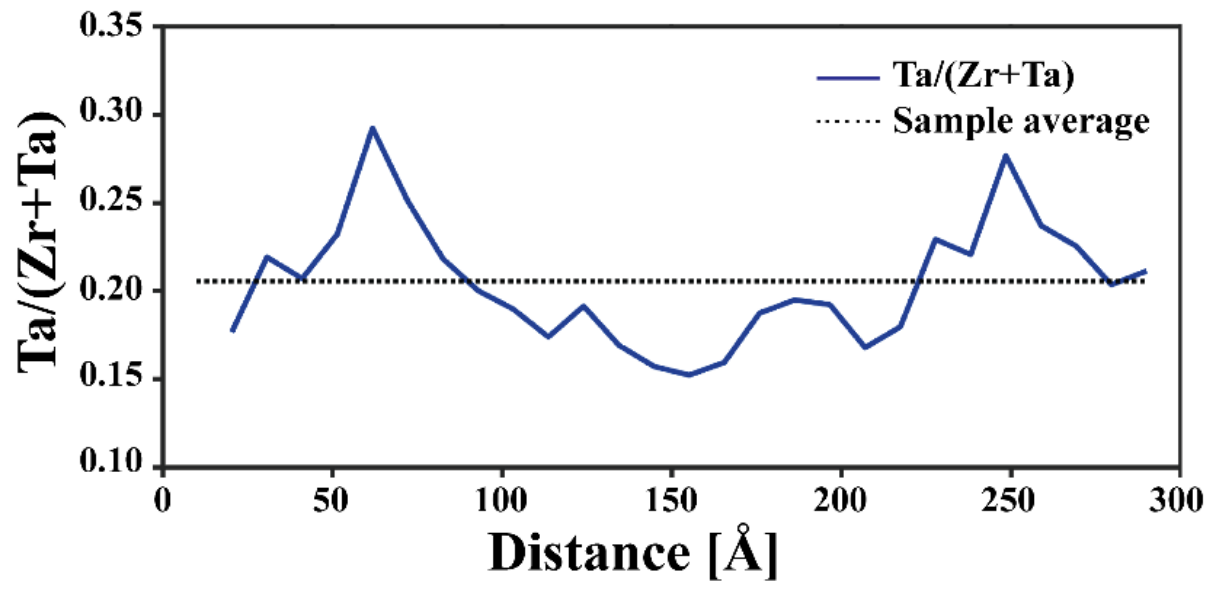

Fig. 6. (a) Two-dimensional APT map of the $\mathrm{Ta} /(\mathrm{Zr}+\mathrm{Ta})$ fraction in a $30-\AA$-thick slab of a $\mathrm{Zr}_{0.8} \mathrm{Ta}_{0.2} \mathrm{~B}_{1.8}$ film grown on $\mathrm{Si}(001)$ at $475{ }^{\circ} \mathrm{C}$ in pure $\mathrm{Ar}(3 \mathrm{mTorr})$ by hybrid Ta-HiPIMS/ZrB 2 DCMS, with $50-\mu$ s HiPIMS pulses, at $\mathscr{P}_{\mathrm{Ta}}=1200 \mathrm{~W}$. A negative substrate bias $\mathrm{V}_{\mathrm{s}}=100 \mathrm{~V}$ is applied in synchronous with the Ta-ion-rich portion of each pulse. The map contains a portion of a typical column with adjacent boundaries. The Ta fraction corresponds to the false-color scale on the right side of the panel. (b) A one-dimensional $\mathrm{Ta} /(\mathrm{Zr}+\mathrm{Ta})$ profile, with an experimental uncertainty of $<0.02$, across the region highlighted by the $300 \times 300 \AA^{2}$ black square in panel (a). The film growth direction is along the cone-shaped sample. 
Ta $4 f$ and $\mathrm{Zr} 4 \mathrm{p}$ XPS core-level spectra obtained from $\mathrm{Zr}_{1-\mathrm{x}} \mathrm{Ta}_{\mathrm{x}} \mathrm{B}_{\mathrm{y}}$ films are shown in Fig. 7. Deconvoluted spin-split $4 \mathrm{p}_{3 / 2}-4 \mathrm{p}_{1 / 2}$ doublet peaks from $\mathrm{ZrB}_{2.4}$, Fig. 7 (a), are located at 28.0 and $29.6 \mathrm{eV}$. In order to deconvolve the Ta $4 \mathrm{f}$ alloy core-level spectra, the $\mathrm{Zr}_{0.9} \mathrm{Ta}_{0.1} \mathrm{~B}_{2.1}$ spectrum is fit first and the results tested by using the same line shapes, $4 \mathrm{f}_{7 / 2}-4 \mathrm{f}_{5 / 2}$ binding-energy (BE) separation, and $4 \mathrm{f}_{7 / 2} / 4 \mathrm{f}_{5 / 2}$ area ratio -- while varying peak positions, peak areas, and FWHM values -- to fit the doublet peaks from alloys with $x \geq 0$.2. In all cases, the background is subtracted using the Shirley

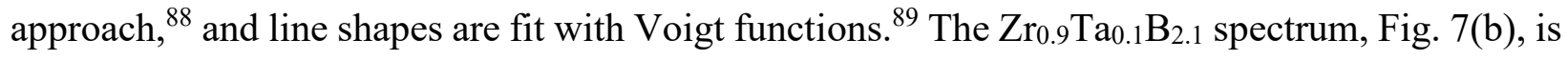
well fit with a single pair of $4 \mathrm{f}_{7 / 2}$ and $4 \mathrm{f}_{5 / 2}$ peaks at $23.2 \mathrm{eV}$ and $25.1 \mathrm{eV}$, respectively. However, the $\mathrm{Ta} 4 \mathrm{f}$ spectra from $\mathrm{Zr}_{0.8} \mathrm{Ta}_{0.2} \mathrm{~B}_{1.8}$ and $\mathrm{Zr}_{0.7} \mathrm{Ta}_{0.3} \mathrm{~B}_{1.5}$ cannot be fit with a single $4 \mathrm{f}$ doublet. Fitting requires an additional set of Ta $4 \mathrm{f}$ peaks at lower BEs, Figs. 7(c) and 7(d). Thus, Ta in alloys with $\mathrm{x} \geq 0.2$ exists in two different chemical states $\left(\mathrm{Ta}_{\mathrm{h}}\right.$ and $\left.\mathrm{Ta} \mathrm{a}\right)$.

The higher-BE $4 \mathrm{f}$ peaks for $\mathrm{Zr}_{0.8} \mathrm{Ta}_{0.2} \mathrm{~B}_{1.8}$ and $\mathrm{Zr}_{0.7} \mathrm{Ta}_{0.3} \mathrm{~B}_{1.5}$ are at the same positions as for $\mathrm{Zr}_{0.9} \mathrm{Ta}_{0.1} \mathrm{~B}_{2.1}$. The lower-BE peaks, at $22.6 \mathrm{eV}$ and $24.5 \mathrm{eV}$, are assigned, based upon the STEM Z-contrast and EELS results in Fig. 4 and 5, together with the APT compositional profile in Fig. 6, to Ta which has segregated to column boundaries. The area ratio of the lower-to-higher BE peaks increases from 0 for $\mathrm{Zr}_{0.9} \mathrm{Ta}_{0.1} \mathrm{~B}_{2.1}$, to 0.2 for $\mathrm{Zr}_{0.8} \mathrm{Ta}_{0.2} \mathrm{~B}_{1.8}$, to 0.3 for $\mathrm{Zr}_{0.7} \mathrm{Ta}_{0.3} \mathrm{~B}_{1.5}$ films, consistent with an increase in $\mathrm{Ta}$ segregation, with higher $\mathrm{Ta} /(\mathrm{Zr}+\mathrm{Ta})$ fractions, to column boundaries, as established by the combination of STEM, EDX, and APT analyses. 


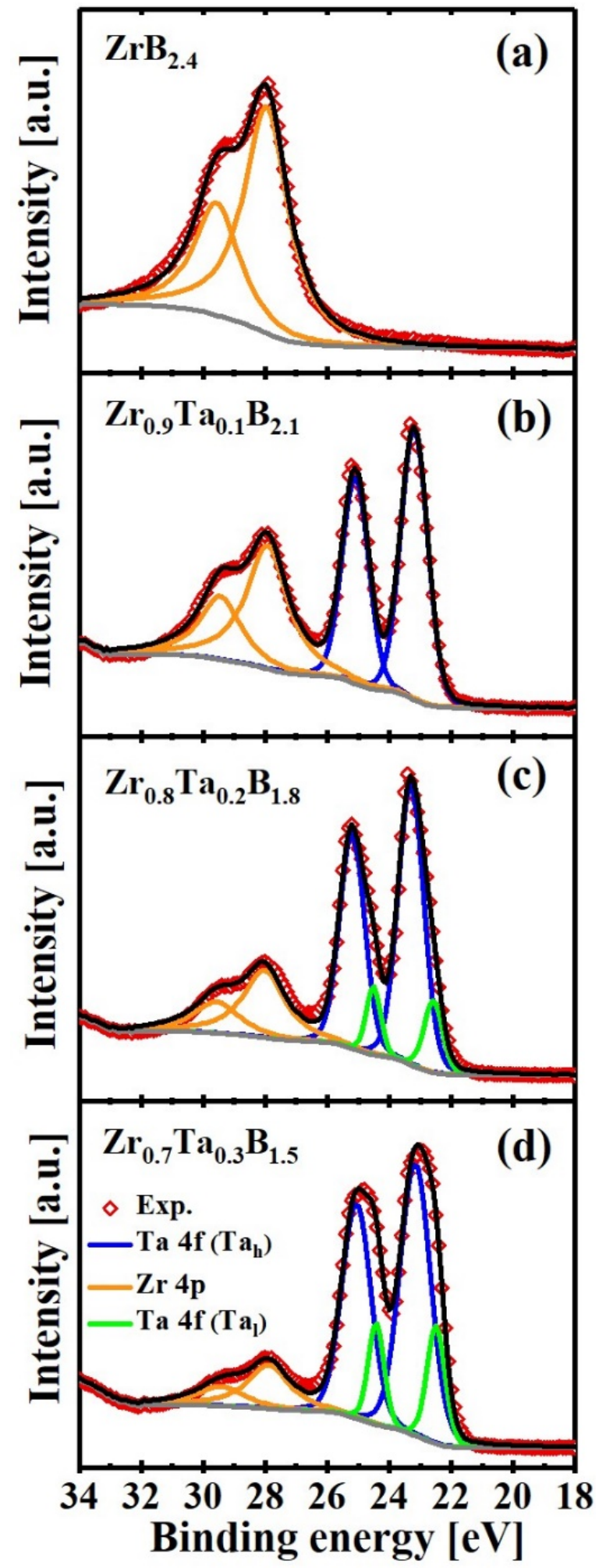

Fig. 7. Ta 4f and $\mathrm{Zr} 4 \mathrm{p}$ XPS core-level spectra acquired from (a) $\mathrm{ZrB}_{2.4}$, (b) $\mathrm{Zr}_{0.9} \mathrm{Ta}_{0.1} \mathrm{~B}_{2.1}$, (c) $\mathrm{Zr}_{0.8} \mathrm{Ta}_{0.2} \mathrm{~B}_{1.8}$, and (d) $\mathrm{Zr}_{0.7} \mathrm{Ta}_{0.3} \mathrm{~B}_{1.5}$ films grown on $\mathrm{Si}(001)$ at $475{ }^{\circ} \mathrm{C}$ in pure $\mathrm{Ar}(3 \mathrm{mTorr})$ by 
hybrid Ta-HiPIMS/ZrB 2 -DCMS, with $50-\mu$ s HiPIMS pulses, as a function of increasing Ta target power $\mathscr{P}_{\text {Ta. }}$. A negative substrate bias $\mathrm{V}_{\mathrm{s}}=100 \mathrm{~V}$ is applied in synchronous with the Ta-ion-rich portion of each pulse.

Fig. 8 shows B 1s and Zr 3d XPS core-level spectra acquired from $Z_{1-x} T_{x} B_{y}$ films with $\mathrm{x}$ ranging from 0 to 0.3 . Peak intensities in each spectrum are normalized to the $\mathrm{Zr} 3 \mathrm{~d}_{5 / 2}$ peak maximum for the corresponding alloy. There is a slight shift in the position of the B 1s peak toward higher binding energy, from $188.1 \mathrm{eV}$ for $\mathrm{ZrB}_{2.4}$ to $188.2 \mathrm{eV}$ for $\mathrm{Zr}_{0.9} \mathrm{Ta}_{0.1} \mathrm{~B}_{2.1}$ to $188.4 \mathrm{eV}$ for both $\mathrm{Zr}_{0.8} \mathrm{Ta}_{0.2} \mathrm{~B}_{1.8}$ and $\mathrm{Zr}_{0.7} \mathrm{Ta}_{0.3} \mathrm{~B}_{1.5}$. We attribute this to the higher electronegativity of Ta compared to $\mathrm{Zr}$, which results in a decrease in the B electron charge density with increasing Ta concentration on the cation sublattice. The $\mathrm{Zr} 3 \mathrm{~d}_{3 / 2}$ and $3 \mathrm{~d}_{5 / 2}$ peak positions at 181.5 and $179.1 \mathrm{eV}$ are in good agreement with expected values for stoichiometric $\mathrm{ZrB}_{2}$. However, they do not exhibit a detectable splitting as observed for the Ta 4 f spectra from $\mathrm{Zr}_{1-\mathrm{x}} \mathrm{Ta}_{\mathrm{x}} \mathrm{B}_{\mathrm{y}}$ alloys with $\mathrm{x} \geq 0.2$ (Fig. 7) since the $\mathrm{Zr}$ 3d peak positions for $\mathrm{Zr}$ metal and $\mathrm{ZrB}_{2}$ are very close (e.g., 178.9 vs. $179.0 \mathrm{eV}$ for $\mathrm{Zr} 3 \mathrm{~d}_{5 / 2}$ ). ${ }^{90,91}$

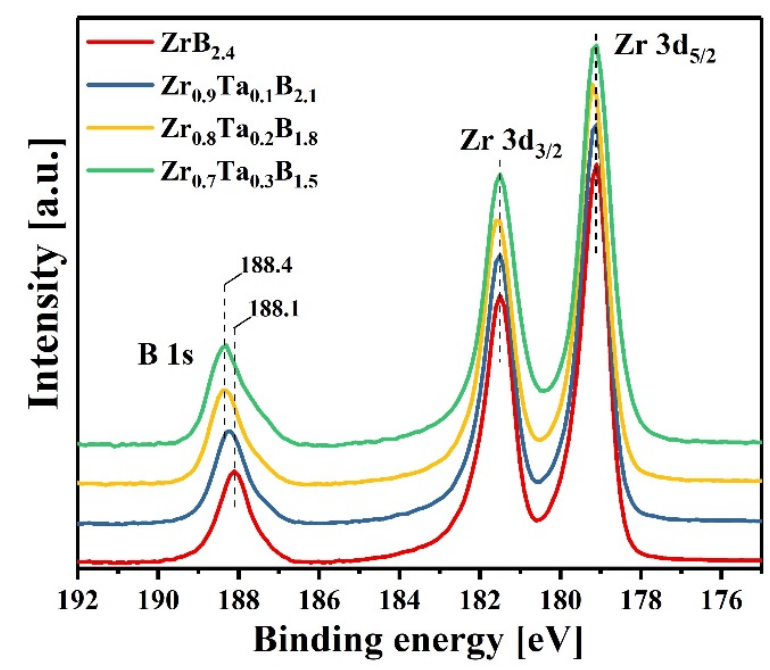

Fig. 8. B $1 \mathrm{~s}$ and $\mathrm{Zr} 3 \mathrm{~d}$ XPS core-level spectra acquired from $\mathrm{ZrB}_{2.4}, \mathrm{Zr}_{0.9} \mathrm{Ta}_{0.1} \mathrm{~B}_{2.1}$, $\mathrm{Zr}_{0.8} \mathrm{Ta}_{0.2} \mathrm{~B}_{1.8}$, and $\mathrm{Zr}_{0.7} \mathrm{Ta}_{0.3} \mathrm{~B}_{1.5}$ films grown on $\mathrm{Si}(001)$ at $475{ }^{\circ} \mathrm{C}$ in pure $\mathrm{Ar}(3 \mathrm{mTorr})$ by hybrid 
Ta-HiPIMS/ZrB 2 -DCMS, with $50-\mu$ s HiPIMS pulses, as a function of increasing Ta target power $\mathcal{P}_{\text {Ta. }}$. A negative substrate bias $\mathrm{V}_{\mathrm{s}}=100 \mathrm{~V}$ is applied in synchronous with the Ta-ion-rich portion of each pulse.

Residual stresses for all films on $\mathrm{Al}_{2} \mathrm{O}_{3}(0001)$ are compressive with $\sigma_{\mathrm{f}}=0.5 \pm 0.1 \mathrm{GPa}$ for $\mathrm{ZrB}_{2.4}, 0.3 \pm 0.1 \mathrm{GPa}$ for $\mathrm{Zr}_{0.9} \mathrm{Ta}_{0.1} \mathrm{~B}_{2.1}, 1.5 \pm 0.3 \mathrm{GPa}$ for $\mathrm{Zr}_{0.8} \mathrm{Ta}_{0.2} \mathrm{~B}_{1.8}$, and $1.8 \pm 0.3 \mathrm{GPa}$ for $\mathrm{Zr}_{0.7} \mathrm{Ta}_{0.3} \mathrm{~B}_{1.5}$. Fig. 9(a) shows film nanoindentation hardnesses $\mathrm{H}$ and elastic moduli $\mathrm{E}$ as a function of $\mathrm{x}$. The hardness of $\mathrm{ZrB}_{2.4}$ is $35.0 \pm 0.6 \mathrm{GPa}$, which increases to $37.0 \pm 1 \mathrm{GPa}$ for $\mathrm{Zr}_{0.9} \mathrm{Ta}_{0.1} \mathrm{~B}_{2.1}$ and $\sim 42.0 \mathrm{GPa}$ for both $\mathrm{Zr}_{0.8} \mathrm{Ta}_{0.2} \mathrm{~B}_{1.8}$ and $\mathrm{Zr}_{0.7} \mathrm{Ta}_{0.3} \mathrm{~B}_{1.5}$. The elastic modulus gradually increases from $488 \pm 10 \mathrm{GPa}$ for $\mathrm{ZrB}_{2.4}$ to $504 \pm 8 \mathrm{GPa}$ for $\mathrm{Zr}_{0.8} \mathrm{Ta}_{0.2} \mathrm{~B}_{1.8}$, then decreases slightly to $490 \pm 10 \mathrm{GPa}$ for $\mathrm{Zr}_{0.7} \mathrm{Ta}_{0.3} \mathrm{~B}_{1.5}$. Both the $\mathrm{H} / \mathrm{E}$ ratio, a qualitative indicator of film toughness, ${ }^{92}$ and $\mathrm{H}^{3} / \mathrm{E}^{2}$, an indicator of wear resistance, ${ }^{93}$ increase with increasing $\mathrm{x}$ from 0.18 and 0.071 for $\mathrm{ZrB}_{2.4}$ to 0.20 and 0.075 for $\mathrm{Zr}_{0.9} \mathrm{Ta}_{0.1} \mathrm{~B}_{2.1}, 0.28$ and 0.083 for $\mathrm{Zr}_{0.8} \mathrm{Ta}_{0.2} \mathrm{~B}_{1.8}$, and 0.29 and 0.084 for $\mathrm{Zr}_{0.7} \mathrm{Ta}_{0.3} \mathrm{~B}_{1.5}$, as shown in Fig. 9(b). 


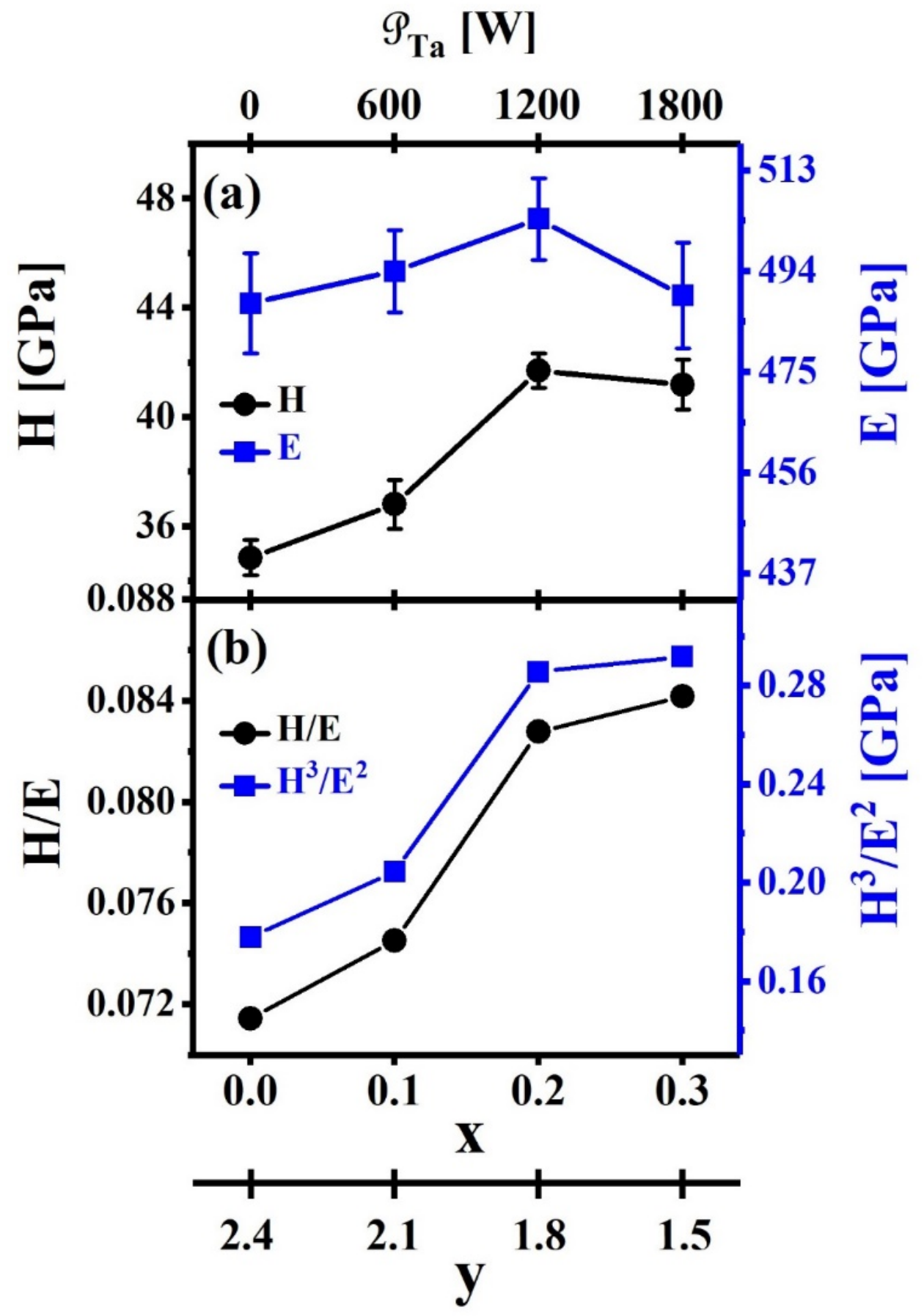

Fig. 9. (a) nanoindentation hardness $H$ and elastic modulus $E$, and (b) $H / E$ and $H^{3} / E^{2}$ ratios for $\mathrm{ZrB}_{2.4}, \mathrm{Zr}_{0.9} \mathrm{Ta}_{0.1} \mathrm{~B}_{2.1}, \mathrm{Zr}_{0.8} \mathrm{Ta}_{0.2} \mathrm{~B}_{1.8}$, and $\mathrm{Zr}_{0.7} \mathrm{Ta}_{0.3} \mathrm{~B}_{1.5}$ films grown on $\mathrm{Al}_{2} \mathrm{O}_{3}(0001)$ at $475{ }^{\circ} \mathrm{C}$ in pure Ar (3 mTorr) by hybrid Ta-HiPIMS/ZrB 2 -DCMS, with 50- $\mu$ s HiPIMS pulses, as a function 
of increasing Ta target power $\mathcal{P}_{\text {Ta }}$. A negative substrate bias $\mathrm{V}_{\mathrm{s}}=100 \mathrm{~V}$ is applied in synchronous with the Ta-ion-rich portion of each pulse.

In order to assess the relative ductility of $\mathrm{Zr}_{1-\mathrm{x}} \mathrm{Ta}_{\mathrm{x}} \mathrm{B}_{\mathrm{y}}$ films, we determine film toughness $\mathrm{K}_{\mathrm{c}}$ via the relationship; ${ }^{77}$

$$
K_{c}=\alpha(E / H)^{0.5}\left(P / C_{m}^{1.5}\right),
$$

in which $\alpha$ is the indenter geometry coefficient, $0.0319 ;{ }^{94} \mathrm{C}_{\mathrm{m}}$ is the average length of radial cracks around a cube-corner indent; and $\mathrm{P}$ is the applied load. Equation 2 was derived for bulk ceramics; ${ }^{77,95}$ thus, in our case, film thickness and substrate effects must be accounted for. An approach which accounts for thickness effects is to measure $\mathrm{K}_{\mathrm{c}}$ at different loads and plot the results as a function of the maximum indentation penetration depth $h_{\max }$, as shown in Fig. 10(a), and then extrapolate the results to $\mathrm{h}_{\max }=0 .{ }^{96}$ Note, however, that the choice of load range influences extracted $\mathrm{K}_{\mathrm{c}}$ values since the substrate can affect results obtained at high loads. Thus, we have chosen load ranges such that $\mathrm{h}_{\max }$ is always less than $30 \%$ of the film thickness.

Fig. 10(a) shows measured $\mathrm{K}_{\mathrm{c}}$ values for $\mathrm{Zr}_{1-\mathrm{x}} \mathrm{Ta}_{\mathrm{x}} \mathrm{B}_{\mathrm{y}}$ alloys as a function of $\mathrm{h}_{\max }$. The minimum nanoindentation force required to create radial cracks with a sharp cube-corner indenter is $10 \mathrm{mN}$ for $\mathrm{ZrB}_{2.4}$ and $\mathrm{Zr}_{0.9} \mathrm{Ta}_{0.1} \mathrm{~B}_{2.1}$ films, and $15 \mathrm{mN}$ for $\mathrm{Zr}_{0.8} \mathrm{Ta}_{0.2} \mathrm{~B}_{1.8}$ and $\mathrm{Zr}_{0.7} \mathrm{Ta}_{0.3} \mathrm{~B}_{1.5} . \mathrm{K}_{\mathrm{c}}$ is highest, over the entire load range, for $\mathrm{Zr}_{0.7} \mathrm{Ta}_{0.3} \mathrm{~B}_{1.5}$. The $\mathrm{K}_{\mathrm{c}}$ vs. $\mathrm{x}$ results in Fig. 10(b), obtained by extrapolating the results in Fig. 10 (a) to $h_{\max }=0$, show that $K_{c}$ initially decreases from 4.0 $\mathrm{MPa} \sqrt{\mathrm{m}}$ for $\mathrm{ZrB}_{2.4}$ to $3.5 \mathrm{MPa} \sqrt{\mathrm{m}}$ for $\mathrm{Zr}_{0.9} \mathrm{Ta}_{0.1} \mathrm{~B}_{2.1}$, then increases to $4.6 \mathrm{MPa} \sqrt{\mathrm{m}}$ for $\mathrm{Zr}_{0.8} \mathrm{Ta}_{0.2} \mathrm{~B}_{1.8}$ and 5.2 MPa $\sqrt{m}$ for $\mathrm{Zr}_{0.7} \mathrm{Ta}_{0.3} \mathrm{~B}_{1.5}$. In order to check that film compressive stress is not having a significant effect on $\mathrm{K}_{\mathrm{c}}$ results, we have recently measured film toughness using the scratch-test method ${ }^{97,98}$-- as part of a new investigation to determine $\mathrm{Zr}_{1-\mathrm{x}} \mathrm{Ta}_{\mathrm{x}} \mathrm{B}_{\mathrm{y}}$ adhesion, wear, and friction - 
- and obtained the same trend. Fig. 10(c) is a plot of the relationship between the hardness and toughness of $\mathrm{Zr}_{1-\mathrm{x}} \mathrm{Ta}_{\mathrm{x}} \mathrm{B}_{\mathrm{y}}$ alloys. In contrast to most hard coatings (e.g., TM nitrides for which TiN and VN serve as model materials systems), ${ }^{99,100}$ which exhibit an increase in brittleness with increasing hardness, ${ }^{92,101-104}$ both hardness and toughness are enhanced for $\mathrm{Zr}_{1-\mathrm{x}} \mathrm{Ta}_{\mathrm{x}} \mathrm{B}_{\mathrm{y}}$ alloys with metal-rich column boundaries.
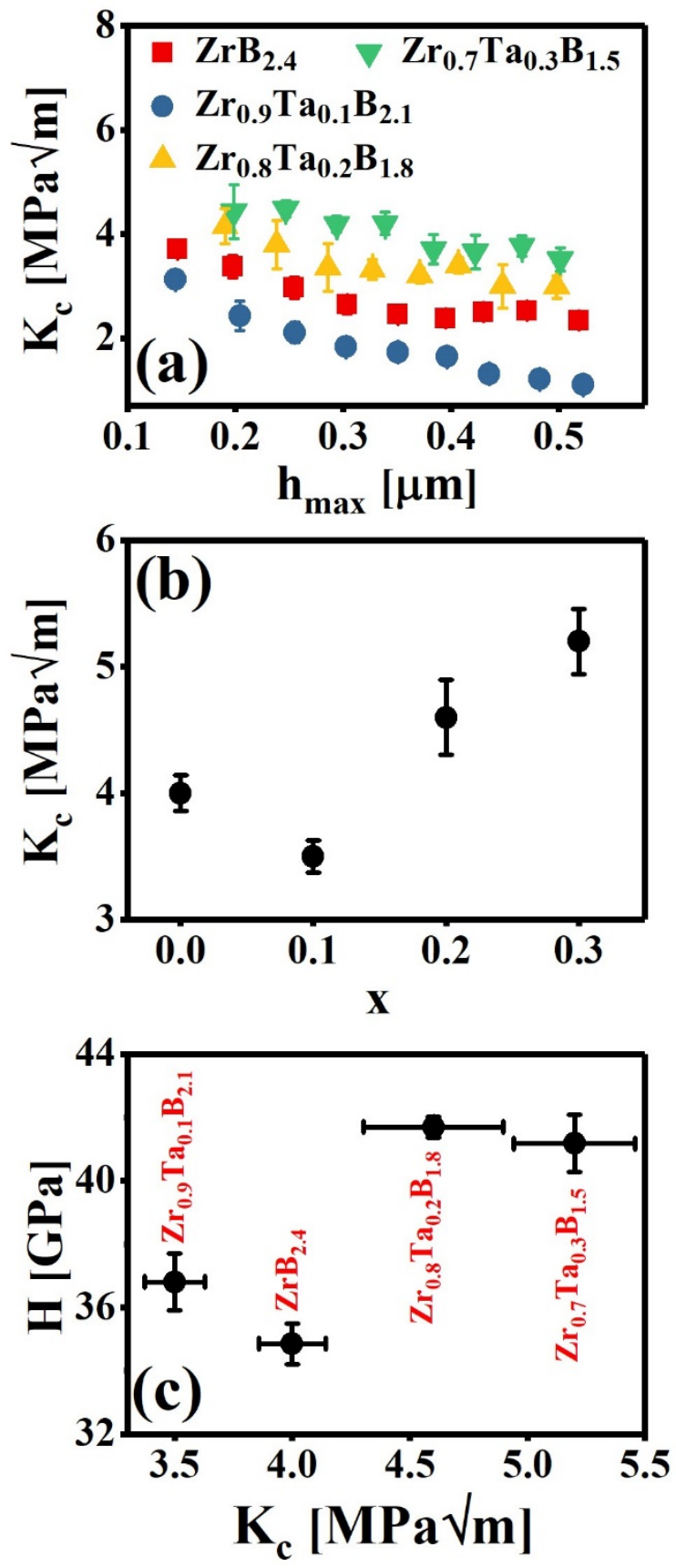
Fig. 10. (a) $\mathrm{Zr}_{1-\mathrm{x}} \mathrm{Ta}_{\mathrm{x}} \mathrm{B}_{\mathrm{y}}$ toughness $\mathrm{K}_{\mathrm{c}}$ as a function of maximum penetration depth $\mathrm{h}_{\max }$ during cube-corner indentation, (b) $\mathrm{K}_{\mathrm{c}}$, after accounting for film thickness and substrate effects, vs. $\mathrm{X}$, and (c) nanoindentation hardness $\mathrm{H}$ vs. $\mathrm{K}_{\mathrm{c}}$ for $\mathrm{Zr}_{1-\mathrm{x}} \mathrm{Ta}_{\mathrm{x}} \mathrm{B}_{\mathrm{y}}$ films grown on $\mathrm{Al}_{2} \mathrm{O}_{3}(0001)$ at 475 ${ }^{\circ} \mathrm{C}$ in pure Ar (3 mTorr) by hybrid Ta-HiPIMS/ZrB2-DCMS, with $50-\mu$ s HiPIMS pulses, as a function of increasing Ta target power $\mathcal{P}_{\text {Ta }}$. A negative substrate bias $\mathrm{V}_{\mathrm{s}}=100 \mathrm{~V}$ is applied in synchronous with the Ta-ion-rich portion of each pulse.

\section{B. Discussion}

$\mathrm{ZrB}_{2}$-rich $\mathrm{Zr}_{1-\mathrm{x}} \mathrm{Ta}_{\mathrm{x}} \mathrm{B}_{\mathrm{y}}(0 \leq \mathrm{x} \leq 0.3)$ films are grown in pure $\mathrm{Ar}(3 \mathrm{mTorr})$ by hybrid TaHiPIMS/ZrB 2 -DCMS co-sputtering in which the $\mathrm{ZrB}_{2}$ target is sputtered in de mode, while heavy Ta ions are provided by HiPIMS sputtering of a Ta target as a function of $\mathcal{P}_{\mathrm{Ta}}$, with a negative substrate bias $\mathrm{V}_{\mathrm{s}}=100 \mathrm{~V}$ synchronized to Ta-ion rich portion of each HiPIMS pulse in order to vary the $\mathrm{B} / \mathrm{TM}$ ratio and provide a dense nanostructure. The $\mathrm{Zr}_{1-\mathrm{x}} \mathrm{Ta}_{\mathrm{x}} \mathrm{B}_{\mathrm{y}} \mathrm{Ta} /(\mathrm{Zr}+\mathrm{Ta})$ ratio increases linearly from $\mathrm{x}=0.1$ to 0.2 to 0.3 with increasing $\mathcal{P}_{\mathrm{Ta}}$ from 600 to 1200 to $1800 \mathrm{~W}$, while the energy per pulse is maintained constant, in order to provide the same peak current density, $\mathbf{J}_{\mathrm{T} \text {,peak }}$ $=0.7 \mathrm{~A} / \mathrm{cm}^{2}$, for all film-growth experiments. The expected values of the $\mathrm{B} /(\mathrm{Zr}+\mathrm{Ta})$ ratio y due to increasing the Ta flux, starting with the reference DCMS sample composition $\mathrm{ZrB}_{2.4}$, are 2.16, 1.96, and 1.80 for the three HiPIMS powers used; however, the measured y values are 2.1, 1.8, and 1.5 , respectively. We attribute the differences to preferential sputtering of light B atoms. ${ }^{105}$

Ta ions incident at the growing films during HiPIMS pulses are much heavier than the majority film constituents $\left(\mathrm{m}_{\mathrm{Ta}}=180.9 \mathrm{amu}, \mathrm{m}_{\mathrm{Zr}}=91.2 \mathrm{amu}\right.$, and $\left.\mathrm{m}_{\mathrm{B}}=10.8 \mathrm{amu}\right)$. The maximum energy transfer in binary head-on collisions with target atoms is given by ${ }^{106}$

$$
\gamma=4 m_{T a} m_{T} /\left(m_{T a}+m_{T}\right)^{2}
$$


in which $\mathrm{m}_{\mathrm{T}}$ is the mass of the target atom involved in the collision. $\gamma$ values for Ta collisions with $\mathrm{Zr}$ and B atoms are 0.89 and 0.21 , respectively. Due to the better mass match, energy is transferred much more efficiently to $\mathrm{Zr}$ than to $\mathrm{B}$. In addition, the heavy Ta-ion projectiles exhibit relatively little sideways scattering, while producing a significant number of lattice recoils, because of the large mass mismatch with the average lattice atomic mass.

We carry out TRIM $^{107}$ simulations of ion-irradiation-induced collisions during film growth. Time- and energy-resolved mass spectroscopy measurements show that $\mathrm{Ta}^{+}$constitutes $>$ $90 \%$ of the ion flux. The projected range plus straggle for $100 \mathrm{eV} \mathrm{Ta}^{+}$ions incident at $\mathrm{Zr}_{0.8} \mathrm{Ta}_{0.2} \mathrm{~B}_{1.8}$ is $22 \AA$; corresponding values for lattice recoils are $17 \AA$ for $\mathrm{Zr}$ and Ta, and $11 \AA$ for B. Thus, B recoils remain much closer to the surface due to poor energy transfer from the heavy Ta atoms, while $\mathrm{Zr}$ and Ta recoils absorb most of the deposited energy and penetrate deeper into the growing film. The heavy-metal ion irradiation leads to densification, as shown previously for TM nitrides deposited by the hybrid HiPIMS/DCMS technique,${ }^{54}$ with intense ion mixing of the metal atoms, due to overlapping cascades, several monolayers deep. The light B atoms tend to accumulate at, and near, the film growth surface and are subjected to preferential resputtering.

The change in the nanostructure and compositional distribution of $\mathrm{Zr}_{1-\mathrm{x}} \mathrm{Ta}_{\mathrm{x}} \mathrm{B}_{\mathrm{y}}$ alloys with increasing $\mathrm{x}$-- as observed by XTEM, STEM Z-contrast, and APT -- can be understood by considering the corresponding decrease in $\mathrm{y} . \mathrm{ZrB}_{2.4}$ films grown by DCMS have a nanostructure similar to the one reported for $\mathrm{TiB}_{2.4}$ deposited by magnetically-unbalanced magnetron sputtering. ${ }^{86}$ It is composed of crystalline columns, with average diameter $\langle d\rangle=90 \pm 20 \AA$, separated by a B tissue phase as shown by the dark contrast in the Z-contrast image in Fig. 4(a) and the EELS data in Fig. 5(c). With $\mathscr{P}_{\mathrm{Ta}}=600 \mathrm{~W}$, the overstoichiometry is reduced from $\mathrm{y}=2.4$ to 2.1 , and the decrease in excess $\mathrm{B}$, coupled with $\mathrm{Ta}^{+}$-ion-irradiation enhanced adatom mobility, 
leads to an increase in $\langle d\rangle$ to $320 \pm 130 \AA$. However, the column boundaries remain B-rich. Since both $\mathrm{ZrB}_{2}$ and $\mathrm{TaB}_{2}$ are line-compounds, ${ }^{44,108}$ we expect that the columnar grains are nearstoichiometric in all films.

As the Ta-HiPIMS power is increased further to 1200 and $1800 \mathrm{~W}$, y decreases to 1.8 and 1.5 as $\mathrm{x}$ increases to 0.2 and 0.3 , which dramatically changes the nanostructure. $\langle d\rangle$ decreases to 110 and $80 \AA$ with the column boundary tissue phase changing from B-rich to metal-rich, as evidenced by the dark contrast in BF XTEM, and bright contrast in STEM Z-contrast images (Fig. 4). APT results, Fig. 6(b), reveal that $\mathrm{Ta}$ is incorporated preferentially at column boundaries, and the EELS scans in Fig. 5 show that the boundaries contain less B than the columns.

Based upon XRD and SAED results, $\mathrm{ZrB}_{2.4}$ and $\mathrm{Zr}_{0.9} \mathrm{Ta}_{0.1} \mathrm{~B}_{2.1}$ films have a mixed $0001 / 10 \overline{1} 0$ texture. This is a result of relatively-weak momentum transfer during growth of these layers leading to random orientation during nucleation and the lack of texture selection during column growth ${ }^{109}$ since the ions are primarily $\mathrm{Ar}^{+}$with a much lower mass than $\mathrm{Ta}$ and $\mathrm{Zr}$. Films with metal-rich grain boundaries, $\mathrm{Zr}_{0.8} \mathrm{Ta}_{0.2} \mathrm{~B}_{1.8}$ and $\mathrm{Zr}_{0.7} \mathrm{Ta}_{0.3} \mathrm{~B}_{1.5}$, have an increasingly stronger 0001 texture, corresponding to the low surface-energy orientation for hexagonal crystals,${ }^{47}$ due to the more intense $\mathrm{Ta}^{+}$ion flux. The 0001 and $0002 \mathrm{x}$-ray peak positions for these alloys shift toward $\mathrm{TaB}_{2}$ reference values showing that, in agreement with APT results, Ta is incorporated both in the columns and in the boundaries.

The intrinsic $\mathrm{ZrB}_{2.4}$ compressive stress, $\sim 0.5 \mathrm{GPa}$, is relatively low for sputter-deposited films due to the low trapped Ar concentration, $<0.5$ at $\%$. The compressive stress in $\mathrm{Zr}_{0.9} \mathrm{Ta}_{0.1} \mathrm{~B}_{2.1}$ layers is even lower, $\sim 0.3 \mathrm{GPa}$, as Ta ion bombardment enhances adatom mobility to provide increased grain size with less trapped Ar due to strong Ar rarefaction during HiPIMS pulses with synchronized substrate bias, while the substrate is at floating potential, $\mathrm{V}_{\mathrm{s}}=\mathrm{V}_{\mathrm{f}}=10 \mathrm{~V}$, at all other 
times. As the Ta ion flux is increased, generating metal-rich column boundaries and decreased average column size, the stress increases to $\sigma_{\mathrm{f}}=\sim 1.5$ and $\sim 1.8 \mathrm{GPa}$ for $\mathrm{Zr}_{0.8} \operatorname{Ta}_{0.2} \mathrm{~B}_{1.8}$ and $\mathrm{Zr}_{0.7} \mathrm{Ta}_{0.3} \mathrm{~B}_{1.5}$, due primarily to residual Ta-ion-induced lattice defects.

Sputter-deposited $\mathrm{ZrB}_{2.4}$ films have a high hardness, $\mathrm{H}=35 \mathrm{GPa}$, compared to $\mathrm{H}=21-23$ GPa for stoichiometric bulk $\mathrm{ZrB}_{2},{ }^{110,111}$ due to the formation of a thin B-rich tissue phase, with strong covalent bonding, at the column boundaries which inhibits column-boundary sliding. ${ }^{86} \mathrm{H}$ increases slightly to $\sim 37 \mathrm{GPa}$ for $\mathrm{Zr}_{0.9} \mathrm{Ta}_{0.1} \mathrm{~B}_{2.1}$, which we attribute primarily to solid-solution hardening. ${ }^{12} \mathrm{Zr}_{0.8} \mathrm{Ta}_{0.2} \mathrm{~B}_{1.8}$ and $\mathrm{Zr}_{0.7} \mathrm{Ta}_{0.3} \mathrm{~B}_{1.5}$ have even higher hardness values, $42 \mathrm{GPa}$, due to increased solid-solution hardening. The decrease in column width, from $\sim 300 \AA$ for $\mathrm{Zr}_{0.9} \mathrm{Ta}_{0.1} \mathrm{~B}_{2.1}$ to $\sim 110 \AA$ and $\sim 80 \AA$ for $\mathrm{Zr}_{0.8} \mathrm{Ta}_{0.2} \mathrm{~B}_{1.8}$ and $\mathrm{Zr}_{0.7} \mathrm{Ta}_{0.3} \mathrm{~B}_{1.5}$, also adds to the film hardness via the Hall-Petch effect. ${ }^{113,114}$

In addition to the increase in hardness, $\mathrm{Zr}_{0.8} \mathrm{Ta}_{0.2} \mathrm{~B}_{1.8}$ and $\mathrm{Zr}_{0.7} \mathrm{Ta}_{0.3} \mathrm{~B}_{1.5}$ alloys also exhibit an increase in toughness, as shown in Fig. 10(c). $\mathrm{K}_{\mathrm{c}}$ initially decreases from 4.0 MPa $\sqrt{\mathrm{m}}$ for $\mathrm{ZrB}_{2.4}$, to $3.5 \mathrm{MPa} \sqrt{\mathrm{m}}$ for $\mathrm{Zr}_{0.9} \mathrm{Ta}_{0.1} \mathrm{~B}_{2.1}$, and then increases to 4.6 and $5.2 \mathrm{MPa}{ }_{\mathrm{m}}$ for $\mathrm{Zr}_{0.8} \mathrm{Ta}_{0.2} \mathrm{~B}_{1.8}$ and $\mathrm{Zr}_{0.7} \mathrm{Ta}_{0.3} \mathrm{~B}_{1.5}$. The nanostructures of these alloys consist of a hard columnar phase with metal-rich boundaries which inhibit crack propagation, while allowing grain-boundary sliding, under heavy loads. Thus, $\mathrm{Zr}_{0.8} \mathrm{Ta}_{0.2} \mathrm{~B}_{1.8}$ and $\mathrm{Zr}_{0.7} \mathrm{Ta}_{0.3} \mathrm{~B}_{1.5}$ alloys exhibit a dual hard/tough nature; the tough metal-rich phase at boundaries accommodates ductility, while the stiff nanosized columns provide high hardness.

\section{CONCLUSIONS}

We demonstrate control of the composition and nanostructure -- and, hence, the physical properties -- of $\mathrm{ZrB}_{2}$-rich $\mathrm{Zr}_{1-\mathrm{x}} \mathrm{Ta}_{\mathrm{x}} \mathrm{B}_{\mathrm{y}}(0 \leq \mathrm{x} \leq 0.3)$ alloy films grown by hybrid Ta-HIPIMS/ZrB ${ }_{2-}$ 
DCMS co-sputtering, in pure Ar, using pulsed heavy-metal Ta-ion bombardment. For alloy growth, the $\mathrm{ZrB}_{2}$ target is continuously sputtered in dc magnetron mode, with the substrate at a negative floating potential $\mathrm{V}_{\mathrm{s}}=10 \mathrm{~V}$, while pulsed Ta-ion irradiation is provided by applying a negative $100 \mathrm{~V}$ substrate bias synchronized with the Ta-ion-rich portion of each HIPIMS pulse. The HiPIMS target power and pulse frequency are increased from 600 to $1800 \mathrm{~W}$, and 100 to 300 $\mathrm{Hz}$, to maintain the energy per pulse constant in order to provide a peak current density per pulse of $0.7 \mathrm{~A} / \mathrm{cm}^{2}$. This results in the B-to-metal ratio decreasing from 2.4 for reference $\mathrm{ZrB}_{2.4}$ layers, deposited by DCMS with $\mathrm{V}_{\mathrm{s}}=100 \mathrm{~V}$, to $2.1,1.8$, and 1.5, as $\mathrm{x}$ in $\mathrm{Zr}_{1-\mathrm{x}} \mathrm{Ta}_{\mathrm{x}} \mathrm{B}_{\mathrm{y}}$ alloy layers increases from 0 to $0.1,0.2$, and 0.3 , due both to the addition of Ta (primarily) and preferential $\mathrm{B}$ resputtering.

TRIM Monte Carlo simulations show that Ta-ion irradiation during $\mathrm{Zr}_{1-\mathrm{x}} \mathrm{Ta}_{\mathrm{x}} \mathrm{B}_{\mathrm{y}}$ film growth results in $\mathrm{B}$ recoils coming to rest, because of the large $\mathrm{B} / \mathrm{Ta}$ mass mismatch, in the near-surface region $(<11 \AA$ ), while $\mathrm{Zr}$ and Ta recoils absorb more deposited energy and undergo intense ioninduced mixing, resulting from overlapping collision cascades, in a region extending to $17 \AA$. Primary Ta ions are implanted even deeper, to $22 \AA$. As a result, all alloy films are fully dense with relatively low compressive stresses ranging from 0.5 to $1.8 \mathrm{GPa}$. Films with $0 \leq \mathrm{x} \leq 0.1$ consist of columnar stoichiometric-diboride grains encapsulated with a B-rich tissue phase, while alloy films with $x \geq 0.2$ have a nanocolumnar structure with metal-rich boundaries. The latter alloys exhibit the highest hardness, $\sim 42 \mathrm{GPa}$ (compared to $36 \mathrm{GPa}$ for reference $\mathrm{ZrB}_{2.4}$ films) due to solidsolution hardening combined with a much smaller grain size (the Hall-Petch effect). Film toughness increases from $\mathrm{K}_{\mathrm{c}}=4.0 \mathrm{MPa} \sqrt{\mathrm{m}}$ for $\mathrm{ZrB}_{2.4}$ to $5.2 \mathrm{MPa} \sqrt{\mathrm{m}}$ for $\mathrm{Zr}_{0.7} \mathrm{Ta}_{0.3} \mathrm{~B}_{1.5}$ as the metalrich boundaries inhibit crack propagation, while allowing grain-boundary sliding under heavy loads. 


\section{ACKNOWLEDGEMENTS}

The authors gratefully acknowledge Ingemar Persson for assistance with EELS analyses. Financial support from the Swedish Research Council VR Grant 2014-5790, 2018-03957, and 6422013-8020, the Knut and Alice Wallenbergs foundation for a Fellowship Grant and Project funding (KAW 2015.0043), the VINNOVA Grant 2018-04290, an Åforsk foundation grant \#16-359, and Carl Tryggers Stiftelse contracts CTS 15:219, CTS 17:166, and CTS 14:431 is gratefully acknowledged. The authors also acknowledge financial support from the Swedish Government

Strategic Research Area in Materials Science on Functional Materials at Linköping University (Faculty Grant SFO Mat LiU No. 2009 00971).

\section{References}

1. G. Hakansson, J.E. Sundgren, D. McIntyre, J.E. Greene, and W.D. Munz, Thin Solid Films 153, 55 (1987).

2. U. Helmersson, S. Todorova, S.A. Barnett, J.E. Sundgren, L.C. Markert, and J.E. Greene, J. Appl. Phys. 62, 481 (1987).

3. J.E. Sundgren, J. Birch, G. Håkansson, L. Hultman, and U. Helmersson, Thin Solid Films 193, 818 (1990).

4. C.S. Shin, D. Gall, N. Hellgren, J. Patscheider, I. Petrov, and J.E. Greene, J. Appl. Phys. 93, 6025 (2003).

5. T. Lee, K. Ohmori, C.S. Shin, D.G. Cahill, I. Petrov, and J.E. Greene, Phys. Rev. B 71, 144106 (2005). 
6. H. Kindlund, D.G. Sangiovanni, J. Lu, J. Jensen, V. Chirita, I. Petrov, J.E. Greene, and L. Hultman, J. Vac. Sci. Technol. 32, 030603 (2014).

7. P. Hedenqvist, M. Bromark, M. Olsson, S. Hogmark, and E. Bergmann, Surf. Coat. Technol. 63,115 (1994).

8. T. Polcar, T. Kubart, R. Novák, L. Kopecký, and P. Široký, Surf. Coat. Technol. 193, 192 (2005).

9. D. McIntyre, J.E. Greene, G. Håkansson, J.E. Sundgren, and W.D. Münz, J. Appl. Phys. 67, 1542 (1990).

10. L.A. Donohue, I.J. Smith, W.-D. Münz, I. Petrov, and J.E. Greene, Surf. Coat. Technol. 94, 226 (1997).

11. J.C. Sánchez-López, D. Martínez-Martínez, C. López-Cartes, A. Fernández, M. Brizuela, A. García-Luis, and J.I. Oñate, J. Vac. Sci. Technol. 23, 681 (2005).

12. C. Hu, Y. Tian, and W. Zheng, Innovations Corrosion and Materials Sci. 5, 2 (2015).

13. D. Gall, I. Petrov, and J.E. Greene, J. Appl. Phys. 89, 401 (2001).

14. A.B. Mei, B.M. Howe, C. Zhang, M. Sardela, J.N. Eckstein, L. Hultman, A. Rockett, I. Petrov, and J.E. Greene, J. Vac. Sci. Technol. A 31, 061516 (2013).

15. A.B. Mei, A. Rockett, L. Hultman, I. Petrov, and J.E. Greene, J. Appl. Phys. 114, 193708 (2013).

16. A.B. Mei, M. Tuteja, D.G. Sangiovanni, R.T. Haasch, A. Rockett, L. Hultman, I. Petrov, and J.E. Greene, J. Mater. Chem. C 4, 7924 (2016).

17. Q. Zheng, A.B. Mei, M. Tuteja, D.G. Sangiovanni, L. Hultman, I. Petrov, J.E. Greene, D.G. Cahill, Phys. Rev. Materials 1, 065002 (2017).

18. Q. Gu, G. Krauss, and W. Steurer, Adv. Mater. 20, 3620 (2008). 
19. A.A. Goncharov, S.N. Dub, A.V. Agulov, and V.V. Petukhov, J. Superhard Mater. 37, 422 (2015).

20. A.I. Bazhin, A.A. Goncharov, A.D. Pogrebnyak, V.A. Stupak, and S.A. Goncharova, Phy. Met. Metallogr. 117, 594 (2016).

21. V. Moraes, H. Riedl, C. Fuger, P. Polcik, H. Bolvardi, D. Holec, and P.H. Mayrhofer, Sci. Repts. 8, 9288 (2018).

22. Y. Murata, U. S. Patent, 3487594 (1970).

23. M. Zhou, M. Nose, Y. Makino and K. Nogi, Thin Solid Films, 343, 234 (1999).

24. R. Telle, L.S. Sigl, and K. Takagi, Boride-Based Hard Materials, in: R. Riedel (Ed.), Handbook of Ceramic Hard Materials, WILEY-VCH Verlag GmbH, 2008, pp. 802-945.

25. See Kennametal Inc., Latrobe, PA, https://www.kennametal.com/en/products/20478624/556249/3925999/4283287/100002780/grad es.html.html; Krosera Hardcoating Technologies, Monroe Falls, OH, http://www.hardcoatingtech.com/documents/TiB2Sheet.pdf; Harvey Tools, Rowley, MA, http://www.harveytool.com/cms/NewsArchive20080927 TiB2COATING_147.aspx; M.A Ford, Davenport, IA, http://www.maford.com/pdf/MAFord_2016_Full\%20Cat_Coatings.pdf.

26. L.A. Friedrich, NASA Technical Report Server, 19810022661 (1981).

27. J.D. Kellner, W.J. Crof and L.A. Shepard, Titanium Diboride Electrodeposited Coatings, Defense Technical Information center, ADA047956 (1997).

28. B.R. Golla, T. Bhandari, A. Mukhopadhyay, and B. Basu, Titanium Diboride, in: W.G. Fahrenholtz, E.J. Wuchina, W.E. Lee, and Y. Zhou (Eds.), Ultra-High Temperature Ceramics: Materials for Extreme Environment Applications, Wiley, Hoboken, NJ, 2014, pp. 316-360.

29. G. Sade and J. Pelleg, Appl. Surf. Sci. 91, 263 (1995). 
30. M. Guziewicz. A. Piotrowska, E. Kamińska, K. Gołaszewska, A. Turos, E. Mizera, A. Winiarski, and J. Szade, Solid State Electron. 43, 1055 (1999).

31. J. Sung, D.M. Goedde, G.S. Girolami and J.R. Abelson, J. Appl. Phys. 91, 3904 (2002).

32. W.J. Clegg, Science 286, 1097 (1999).

33. F. Kunc, J. Musil, P. H. Mayrhofer, and C. Mitterer, Surf. Coat. Technol. 174, 744 (2003).

34. N. Nedfors, A. Mockute, J. Palisaitis, P.O.Å . Persson, L.Å . Näslund, and J. Rosén, Surf. Coat. Technol. 304, 203 (2016).

35. J. Neidhardt, S. Mráz, J.M. Schneider, E. Strub, W. Bohne, B. Liedke, W. Möller, and C. Mitterer, J. Appl. Phys. 104, 063304 (2008).

36. M. Berger, M. Larsson, and S. Hogmark, Surf. Coat. Technol. 124, 253 (2000).

37. I. Petrov, A. Hall, A. Mei, N. Nedfors, I. Zhirkov, J. Rosén, A. Reed, B. Howe, G. Greczynski, J. Birch, L. Hultman and J.E. Greene, J. Vac. Sci. Technol., A 35, 050601 (2017).

38. B. Bakhit, I. Petrov, J.E. Greene, L. Hultman, J. Rosén and G. Greczynski, J. Vac. Sci. Technol. A 36, 030604 (2018).

39. J. Reader and C.H. Corliss, Atomic, molecular, and optical physics; ionization potentials of atoms and atomic ions, in: D.R. Lide (Ed.), CRC Handbook of Chemistry and Physics, $84^{\text {th }}$ ed., CRC, Boca Raton, FL, 2003, Section 10.

40. M.A. Lennon, K.L. Bell, H.B. Gilbody, J.G. Hughes, A.E. Kingston, M.J. Murray, and F.J. Smith, J. Phys. Chem. Ref. Data 17, 1285 (1988).

41. JCPDS International Centre for Diffraction Data. Zirconium diboride $\left(\mathrm{ZrB}_{2}\right)$ card 00-0340423.

42. J.E. Sundgren, B.O. Johansson, A. Rockett, S.A. Barnett, and J.E. Greene, TiN: A Review of the Present Understanding of the Atomic and Electronic Structure and Recent Results on the 
Growth and Physical Properties of Epitaxial $\operatorname{TiN}_{\mathrm{x}}(0.6<\mathrm{x}<.12)$ Layers, in: W.D. Sproul, J.E. Greene, and J.A. Thornton (Eds.), Physics and Chemistry of Protective Coatings, American Institute of Physics Series 149, New York, 1986, pp. 95.

43. L.E. Toth, Transition Metal Carbides and Nitrides, $1^{\text {st }}$ ed., Academic press, San Diego, CA, 1971, pp. 69-101.

44. T. Lundström, Transition metal borides, in: V.I. Matkovich (Ed.), Boron and Refractory Borides, Springer-Verlag, Heidelberg, Germany, 1977, pp. 351-376.

45. A.E. McHale, Data Collected from Phase Diagrams for Ceramists, Vol. X, American Ceramic Society, Westerville, OH, 1994.

46. L. Bsenko, T. Lundström, J. Less-Common Met., 34273 (1974).

47. D.L. Smith, Thin Film Deposition: Principles and Practice, McGraw-Hill, New York, 1995, p. 142.

48. C. Mitterer, P. Losbichler, W.S.M. Werner, H. Störi, and J. Barounig, Surf. Coat. Technol. 54, 329 (1992).

49. W.G. Fahrenholtz, G.E. Hilmas, I.G. Talmy, and J.A. Zaykoski, J. Am. Ceram. Soc. 90, 1347 (2007).

50. J.V. Rau, D. Ferro, M.B. Falcone, A. Generosi, V.R. Albertini, A. Latini, R. Teghil, and S.M. Barinov, Mater. Chem. Phys. 112, 504 (2008).

51. L. Tengdelius, E. Broitman, J. Lu, F. Eriksson, J. Birch, T. Nyberg, L. Hultman, and H. Högberg, Acta Mater. 111, 166 (2016).

52. G. Greczynski, J. Lu, M.P. Johansson, J. Jensen, I. Petrov, J. E. Greene, and L. Hultman, Surf. Coat. Technol. 206, 4202 (2012). 
53. G. Greczynski, J. Lu, M. Johansson, J. Jensen, I. Petrov, J. E. Greene, and L. Hultman, Vacuum $86,1036(2012)$.

54. G. Greczynski, J. Lu, S. Bolz, W. Kölker, C. Schiffers, O. Lemmer, I. Petrov, J. E. Greene, and L. Hultman, J. Vac. Sci. Technol. A 32, 41515 (2014).

55. G. Greczynski, J. Lu, J. Jensen, I. Petrov, J.E. Greene, S. Bolz, W. Kölker, Ch. Schiffers, O. Lemmer, and L. Hultman, J. Vac. Sci. Technol. A 30, 061504 (2012).

56. https://www.cemecon.de/us-en/coating-plants/cc-800-hipims; accessed on 2018-07-15.

57. Thermocouple calibrations are confirmed using boiling water; the maximum allowable deviation is $\pm 2{ }^{\circ} \mathrm{C}$.

58. G. Greczynski and L. Hultman, Vacuum 84, 1159 (2010).

59. G.G. Stoney, Proc. Roy. Soc. Ser. A 82, 172 (1909).

60. G.C.A.M. Janssen, M.M. Abdalla, F.V. Keulen, B.R. Pujada, and B.V. Venrooy, Thin Solid Films 517, 1858 (2009).

61. S. Hearne, E. Chason, J. Han, J.A. Floro, J. Figiel, J. Hunter, H. Amano, and I.S.T. Tsong, Appl. Phys. Lett. 74, 356 (1999).

62. M. Ohring, Materials Science of Thin Films, $2^{\text {nd }}$ ed., Academic, New York, 2001, pp. 1-55.

63. E.R. Dobrovinskaya, L.A. Lytvynov, and V. Pishchik, Sapphire: Material, Manufacturing, Applications, Springer, NY, 2009, pp. 55-153.

64. W.A. Paxton, T.E. Özdemir, İ. Şavklıyıldız, T. Whalen, H. Biçer, E.K. Akdoğan, Z. Zhong, and T. Tsakalakos, Anisotropic Thermal Expansion of Zirconium Diboride: An Energy-Dispersive x-ray Diffraction Study, Journal of Ceramics 2016, Article ID 8346563, (2016).

65. H. Warlimont, Ceramics, in: W. Martienssen and H. Warlimont (Eds.), Springer Handbook of Condensed Matter and Materials Data, chapter 17, Springer, Switzerland, 2005, p. 454. 
66. G. Greczynski, I. Petrov, J.E. Greene, and L. Hultman, J. Vac. Sci. Technol. A 33, 05E101 (2015).

67. ISO 15472:2010, "Surface chemical analysis -- x-ray photoelectron spectrometers -Calibration of energy scales", (ISO, Geneva, 2010).

68. G. Greczynski and L. Hultman, Chem. Phys. Chem. 18, 1507 (2017).

69. K. Thompson, D. Lawrence, D.J. Larson, J.D. Olson, T.F. Kelly, and B. Gorman, Ultramicroscopy 107, 131 (2007).

70. K. Thompson, B. Gorman, D. Larson, B.V. Leer and L. Hong, Microsc. Microanal. 12, 1736 (2006).

71. B.P. Geiser, D.J. Larson, E. Oltman, S. Gerstl, D. Reinhard, T.F. Kelly, and T.J. Prosa, Microsc. Microanal. 15, 292 (2009).

72. H. Ljungcrantz, M. Odén, L. Hultman, J.E. Greene, and J.E. Sundgren, J. Appl. Phys. 80, 6725 (1996).

73. W.C. Oliver and G.M. Pharr, J. Mater. Res. 7, 1564 (1992).

74. N.L. Okamoto, M. Kusakari, K. Tanaka, H. Inui, M. Yamaguchi and S. Otani, J. Appl. Phys. 93, $88(2003)$.

75. W.J. Zhao and Y.X. Wang, J. Solid State Chem. 182, 2880 (2009).

76. J.D. Zhang, X.L. Cheng and D.H. Li, Comp. Mat. Sci. 50, 474 (2010).

77. B.R. Lawn, A.G. Evans, and D.B. Marshall, J. Am. Ceram. Soc. 63, 574 (1980).

78. S.M. Rossnagel, J. Vac. Sci. Technol. A 6, 19 (1988).

79. D.W Hoffman, J. Vac. Sci. Technol. A 3, 561 (1985).

80. G. Greczynski, I. Petrov, J.E. Greene, L. Hultman, Vacuum 116, 36 (2015).

81. JCPDS International Centre for Diffraction Data. Tantalum diboride ( $\left.\mathrm{TaB}_{2}\right)$ card 00-038-1462. 
82. P. Zaumseil, J. Appl. Cryst. 48, 528 (2015).

83. L. Pauling, J. Am. Chem. Soc. 69(3), 542 (1947).

84. B. Post, F.W. Glaser, and D. Moskowitz, Acta Metall. 2, 20 (1954).

85. H.R. Moutinho, F.S. Hasoon, F. Abulfotuh, and L.L. Kazmerski, J. Vac. Sci. Technol. A 13, 2877 (1998).

86. P.H. Mayrhofer, C. Mitterer, J.G. Wen, J.E. Greene, and I. Petrov, Appl. Phys. Lett. 86, 131909 (2005).

87. M.K. Miller and M.G. Hetherington, Surf. Sci. 246, 442 (1991).

88. D.A. Shirley, Phys. Rev. B 5, 4709 (1972).

89. N. Fairley, XPS lineshapes and curve fitting, in: D. Briggs and J.T. Grant (Eds.), Surface Analysis by Auger and x-ray Photoelectron Spectroscopy, (IM Publications, Manchester, 2003, pp. 397-420.

90. J.F. Moulder, W.F. Stickle, P.E. Sobol, and K.D. Bomben, Handbook of x-ray Photoelectron Spectroscopy, Perkin-Elmer Corporation, Eden Prairie, USA, 1992, p. 109.

91. L. Tengdelius, G. Greczynski, M. Chubarov, J. Lu, U. Forsberg, L. Hultman, E. Janzén, and H. Högberg, Stoichiometric, J. Cryst. Growth 430, 55 (2015).

92. J. Musil, Surf. Coat. Technol. 207, 50 (2012).

93. A. Leyland and A. Matthews, Wear 246, 1 (2000).

94. G.M. Pharr, D.S Harding, and W.C. Oliver, Measurement of Fracture Toughness in Thin Films and Small Volumes Using Nanoindentation Methods, in: M. Nastasi, D.M. Parkin, and H. Gleiter (Eds.), Mechanical Properties and Deformation Behavior of Materials Having Ultra-Fine Microstructures, NATO ASI Series, Series E: Applied Sciences, 233, Springer, Netherlands, 1993, pp. $449-461$. 
95. G.R. Anstis, P. Chantikul, B.R. Lawn, and D.B. Marshall, J. Am. Ceram. Soc. 64, 533 (1981).

96. Y.X. Wang, S. Zhang, J.W. Lee, W.S. Lew, and B. Li, Surf. Coat. Technol. 206, 5103 (2012).

97. Y.H. Chena, J.J. Roa, C.H. Yu, M.P. Johansson-Jõesaar, J.M. Andersson, M.J. Anglada, M.

Odén, and L. Rogström, Surf. Coat. Technol. 342, 85 (2018).

98. P. Panjan, M. Cekada, and B. Navinsek, Surf. Coat. Technol. 174, 55 (2003).

99. H. Kindlund, D.G. Sangiovanni, L. Martínez-de-Olcoz, J. Lu, J. Jensen, J. Birch, I. Petrov, J.E.

Greene, V. Chirita, and L. Hultman, J. Vac. Sci. Technol. A 32, 030603 (2014).

100. H. Kindlund, D.G. Sangiovanni, J. Lu, J. Jensen, V.Chirita, J. Birch, I. Petrov, J.E. Greene, and L. Hultman, Acta Mater. 77, 394 (2014).

101. Y.X. Wang and S. Zhang, Surf. Coat. Technol. 258, 1 (2014).

102. R.O. Ritchie, Nat. Mater. 10 (2011) 817.

103. W.J. Clegg, Science 286, 1097 (1999).

104. S.M. Wiederhorn, Annu. Rev. Mater. Sci. 14, 373 (1984).

105. D. Gall, R.T. Haasch, N. Finnegan, T.Y. Lee, C.S. Shin, E. Sammann, J.E. Greene, and I. Petrov, Surf. Sci. Spect. 7, 167 (2000).

106. M. Nastasi, J.W. Mayer, and Y. Wang, Ion Beam Analysis: Fundamentals and Applications, $1^{\text {st }}$ ed., Taylor \& Francis, CRC Press, Boca Raton, 2014, pp. 9-24.

107. J.F. Ziegler, M.D. Ziegler, and J.P. Biersack, SRIM - The Stopping and Range of Ions in Matter (2010), Nucl. Inst. Methods B268, 1818 (2010). The authors used SRIM-2013, available from www.SRIM.org.

108. Facility for the Analysis of Chemical Thermodynamics, http://www.crct.polymtl.ca/fact/documentation/menu.php?SpMCBN=1

109. I. Petrov, P.B. Barna, L. Hultman, and J.E. Greene, J. Vac. Sci. Technol. A 21, S117 (2003). 
110. A.L. Chamberlain, W.G. Fahrenholtz, G.E. Hilmas, and D.T. Ellerby, J. Am. Ceram. Soc. 87, 1170 (2004).

111. Engineering Properties of Borides, in: S.J. Schneider (Ed.), Engineered Materials Handbook Volume 4: Ceramics and Glasses, ASM International, Materials Park, OH, 1991.

112. G.E. Dieter, Mechanical Metallurgy, $3^{\text {rd }}$ ed. Mc Graw-Hill Book Co., New York 1986, pp. 128-132.

113. E.O. Hall, Proc. Phys. Soc. B 64, 747 (1951).

114. N.J. Petch, J. Iron Steel Inst. 174, 25 (1953). 